\title{
The respiratory DC/macrophage network at steady-state and upon influenza infection in the swine biomedical model
}

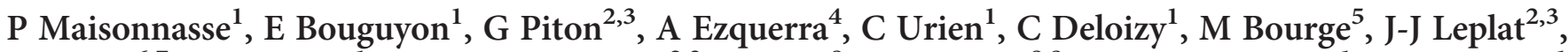

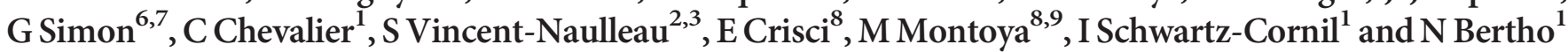

Human and mouse respiratory tracts show anatomical and physiological differences, which will benefit from alternative experimental models for studying many respiratory diseases. Pig has been recognized as a valuable biomedical model, in particular for lung transplantation or pathologies such as cystic fibrosis and influenza infection. However, there is a lack of knowledge about the porcine respiratory immune system. Here we segregated and studied six populations of pig lung dendritic cells (DCs)/macrophages (MOs) as follows: conventional DCs (CDC) 1 and cDC2, inflammatory monocytederived DCs (moDCs), monocyte-derived M $\theta$ s, and interstitial and alveolar M $\theta$ s. The three DC subsets present migratory and naive T-cell stimulation capacities. As observed in human and mice, porcine CDC1 and CDC2 were able to induce T-helper (Th)1 and Th2 responses, respectively. Interestingly, porcine moDCs increased in the lung upon influenza infection, as observed in the mouse model. Pig CDC2 shared some characteristics observed in human but not in mice, such as the expression of $F C \varepsilon R l \alpha$ and Langerin, and an intra-epithelial localization. This work, by unraveling the extended similarities of the porcine and human lung DC/M0 networks, highlights the relevance of pig, both as an exploratory model of DC/M $\theta$ functions and as a model for human inflammatory lung pathologies.

\section{INTRODUCTION}

Pig is being developed as a model for several respiratory pathologies leading to over-inflammation, such as cystic fibrosis, ${ }^{1,2}$ lung transplantation, ${ }^{3}$ and influenza A virus (IAV) infection. ${ }^{4}$ Indeed, pig and human respiratory systems present several anatomical, histological, physiological, and biochemical similarities. ${ }^{5}$ In addition, the pig immune system appears relatively close to the human one, as orthology preservation analysis on immune genes showed a greater similarity between human and pig than between human and mouse. ${ }^{6}$ For instance, and conversely to the murine ones, porcine alveolar macrophages (AMs) show no evidence of nitric oxide production after lipopolysaccharide and/or Concanavalin A stimulations ${ }^{7}$ exhibiting similar behavior to human AMs (for review, see ref. 8). Even if its immune system is one of the best characterized after the human, primate, and murine ones, ${ }^{9}$ so far the few studies that have described pig's lung immune cells did not enter in dendritic cell (DC) and macrophage (M $\theta)$ subpopulation details, ${ }^{10,11}$ limiting its use as a preclinical model for respiratory pathologies.

One of the main components of the respiratory immune system is the DC/M $\theta$ network involved in sensing foreign antigens, controlling inflammation, and initiating the adaptive immune responses. For the sake of clarity, we will use an adaptation of a recently proposed nomenclature from Guilliams et al., ${ }^{12}$ distinguishing two levels of identification. The first level focuses on the origin of the cell-type progenitor (adult bonemarrow proDC for conventional DCs (cDCs), adult blood monocytes for monocyte-derived cells (moCells), or embryonic monocyte-derived precursors settled in peripheral tissues for

\footnotetext{
${ }^{1}$ Virologie et Immunologie Moléculaires UR892, Institut National de la Recherche Agronomique, Jouy-en-Josas, France. ${ }^{2}$ INRA, UMR Génétique Animale et Biologie Intégrative (GABI), Equipe Génétique Immunité Santé, Jouy-en-Josas, France. ${ }^{3}$ Laboratoire de Radiobiologie et Etude du genome, CEA, Direction des Sciences du Vivant, Institut de Radiobiologie Cellulaire et Moléculaire, Jouy-en-Josas, France. ${ }^{4}$ Dpto. de Biotecnología, Instituto Nacional de Investigación y Tecnología Agraria y Alimentaria (INIA), Madrid, Spain. ${ }^{5}$ 2BC, Centre National de la Recherche Scientifique, Gif-sur-Yvette, France. ${ }^{6}$ Anses, Laboratoire de Ploufragan/Plouzané, Unité Virologie Immunologie Porcines, BP53, Ploufragan, France. ${ }^{7}$ Université Européenne de Bretagne, Rennes, France. ${ }^{8}$ Centre de Recerca en Sanitat Animal (CReSA), UAB-IRTA, Campus de la Universitat Autònoma de Barcelona, Bellaterra (Cerdanyola del Vallès), Spain and ${ }^{9}$ The Pirbright Institute, Surrey, UK. Correspondence: NBertho (nicolas.bertho@jouy.inra.fr) 
$\mathrm{M} \theta \mathrm{s}$ ). The second level focuses on the cell functions (M $\theta$-like or DC-like).

In the mouse lung, four different $\mathrm{DC} / \mathrm{M} \theta$ subtypes have been described so far. Two types of cDCs arise from FLT3-dependent proDC. The $\mathrm{cDC} 1$ subset $\left(\mathrm{CD} 103^{\mathrm{pos}} / \mathrm{CD} 172 \mathrm{a}^{\text {neg }} / \mathrm{XCR} 1^{\mathrm{pos}}\right)$ is mainly involved in the induction of primary $\mathrm{CD} 8$ and T-helper 1 (Th1) immune responses, whereas the cDC2 subset $\left(\mathrm{CD} 11 \mathrm{~b}^{\mathrm{pos}} / \mathrm{CD} 172 \mathrm{a}^{\text {pos }} / \mathrm{XCR} 1^{\text {neg }}\right)$ is involved in the induction of Th2 lung immune responses. AMs derive from local precursors settled in the lungs before birth, which renew the AM pool in a bone marrow-independent manner. ${ }^{13,14}$ Finally, an inflammatory monocyte-derived DC (moDC) subset attracted to inflammatory tissues through the CCR2/ CCL2 axis was recently defined as CD64 $4^{\text {pos }} / \mathrm{Fc}_{\mathrm{CRI}} \alpha^{\text {pos }} \cdot{ }^{15}$

In humans, $\mathrm{CD} 141^{\text {pos }} / \mathrm{cDC} 1$ and $\mathrm{CD} 1 \mathrm{c}^{\mathrm{pos}} / \mathrm{cDC} 2$ have been well characterized in blood and skin, ${ }^{16}$ and their functions mainly correspond to the $\mathrm{CDC} 1 / \mathrm{cDC} 2$ mouse paradigm. In the lung, DCs presenting both phenotypes have been described, ${ }^{16,17}$ although only one publication specifically addressed their functions, finding that both $\mathrm{CDC} 1$ and $\mathrm{CDC} 2$ presented antigens equally well to $\mathrm{CD} 8^{+}$memory $\mathrm{T}$ cells. ${ }^{18}$

Human AMs have been widely studied ${ }^{19}$ and behave similarly to the mouse ones, with the exception of nitric oxide production. However, no lung inflammatory moDCs have ever been described in the human lung.

We have previously shown that in the skin, porcine and human DC networks were very similar ${ }^{20,21}$ (for review, see ref. 22). Therefore, pig appears as a pertinent model to explore which murine lung DC/M $\theta$ functions can be extrapolated to other mammals, including humans, at steady state and upon pathological inflammation.

Unlike mice, pigs are natural hosts for IAV. They show identical symptoms and are infected by the same subtypes as humans (H1N1 and H3N2). Although H1N2 viruses have so far only been described in pigs, they might present some zoonotic potential, ${ }^{23}$ like other pig IAV, as highlighted by the $2009 \mathrm{H} 1 \mathrm{~N} 1$ pandemic of swine origin. ${ }^{24}$ Similarly to humans, disease severity in IAV infection in pigs have been associated with increased local pro-inflammatory cytokines. ${ }^{10,25}$ In mice, inflammatory moDCs appear to have an important role in the IAV pathogenesis. Indeed, pharmacological or genetic downregulation of the trafficking of these cells moderates the inflammation without impacting the adaptive immune response and reduces morbidity and mortality. ${ }^{26}$ Upon infection, AMs are thought to mainly downmodulate the pathogen-induced inflammation ${ }^{19}$ and to scavenge cell debris. ${ }^{27}$ Thus, it seems relevant to confirm these results in other species than mouse, where AMs and DCs would then become potential therapeutic targets to reduce the pathological inflammation induced by some IAV. Therefore, pig appears as an ideal experimental animal to study different aspects of the interaction between IAV and the lung immune system.

In this study, we finely define for the first time the phenotypes and functions of DC/M $\theta$ populations in the different compartments of the swine respiratory tract at steady state and upon IAV infections.

\section{RESULTS}

\section{Porcine lung $\mathrm{MHCII}^{\text {high }}$ cells can be divided into six populations of DCs and Mos}

Based on our work on porcine skin, ${ }^{20,21}$ several putative DC populations were identified as MHCII ${ }^{\text {high }}$ in the porcine lung parenchyma (Figure 1a). Among the MHCII ${ }^{\text {high }}$ cells, five populations were distinguished using the CD163 and CD172a $(\operatorname{Sirp} \alpha)$ surface markers. Population 1 was the less frequent $(5.6 \pm 5.1 \%)$ and the only negative one for CD172a expression (Figures 1a,e). Thus, it will hereafter be named CD172 $\mathrm{a}^{\text {neg }}$. The other four MHCII ${ }^{\text {high }}$ populations expressed CD172a and will be named based on their differential CD163 expression level: $2 / \mathrm{CD} 163^{\text {neg }}(11.8 \pm 12.3 \%), \quad 3 / \mathrm{CD} 163^{\text {low }}(17.4 \pm 4.3 \%)$, $4 / \mathrm{CD} 163^{\text {int }}(7.4 \pm 4.3 \%)$, and $5 / \mathrm{CD} 163^{\text {high }}(53.8 \pm 28.1 \%)$. Finally, in the bronchoalveolar lavage (BAL), we also identified one homogeneous $\mathrm{MHCII}{ }^{\mathrm{pos}}$ population as AMs (Figure 1b). These cells were CD172a $\mathrm{a}^{\text {pos }} / \mathrm{CD} 163^{\text {high }}$.

In the parenchyma, the $\mathrm{CD} 172 \mathrm{a}^{\text {neg }}$ population was $\mathrm{CD} 11 \mathrm{~b}$ like $e^{\text {neg }} / \mathrm{CD}^{\text {neg }} / \mathrm{CadM1}^{\text {pos }}$ and did not express the antigen recognized by an anti-human mannose receptor (MR-like) (Figure 1c). The $\mathrm{CD} 163^{\text {neg }}$ population expressed low levels of CD1 and MR-like, and presented both CD11b-like ${ }^{\text {pos }}$ and CD11b-like ${ }^{\text {neg }}$ subpopulations. It also expressed CadM1 but at a lower level than the $\mathrm{CD} 172 \mathrm{a}^{\text {neg }}$ population. The $\mathrm{CD} 163^{\text {low }}$ population was $\mathrm{CD} 11 \mathrm{~b}-\mathrm{like} \mathrm{e}^{\mathrm{pos}} / \mathrm{CD} 1^{\text {neg }} / \mathrm{CadM}^{\mathrm{pos}} / \mathrm{MR}-\mathrm{Clke}^{\text {pos }}$. The $\mathrm{CD} 163^{\text {int }}$ population was $\mathrm{CD} 11 \mathrm{~b}-\mathrm{like} \mathrm{e}^{\mathrm{pos}} / \mathrm{CD} 1^{\text {neg/ }}$ CadM1 $1^{\text {low }} / \mathrm{MR}-$-like $e^{\text {pos }}$ and was the only one expressing CD14. The CD163 ${ }^{\text {high }}$ population did not express CD11b-like, highly expressed MR-like and was autofluorescent, like AMs from BAL. AMs but not CD163 ${ }^{\text {high }}$ cells expressed low levels of CadM1 in three out of four animals. To test the possibility that parenchymal CD163 ${ }^{\text {high }}$ cells were AMs contaminating parenchymal samples, we differentially stained alveolar and parenchymal cells by injecting carboxyfluorescein succinimidyl ester (CFSE) in the bronchiole leading to the intermediate lobe alveoli. Next, the lobe was massaged for a good CFSE diffusion and cells from each compartment were collected separately. As expected, AMs showed strong CFSE staining due to the fact that they were directly in contact with injected CSFE. Conversely, none of the parenchymal cells, including CD163 ${ }^{\text {high }}$ cells, were CFSE stained (Figure 1d), indicating that $\mathrm{AMs}$ and $\mathrm{CD} 163^{\text {high }}$ parenchymal cells belonged to distinct compartments. In the upper respiratory track, the same five different populations of MHCII ${ }^{\text {high }}$ cells were detected in the tracheal mucosa, exhibiting a similar phenotype (Supplementary Data 1a online).

The different populations were sorted and stained on slides using May-Grünwald-Giemsa coloration, to analyze their morphology. As shown in Figure 1f, CD172 ${ }^{\text {neg }}, \mathrm{CD} 163^{\text {neg }}$, and $\mathrm{CD} 163^{\text {low }}$ cells showed DC morphology with dendrites and irregular serrated nuclei, whereas $\mathrm{CD} 163^{\text {int }}, \mathrm{CD} 163^{\text {high }}$, and $\mathrm{AM}$ cells clearly resembled $\mathrm{M} \theta$ s with a vacuolated cytoplasm and a round nucleus.

\section{Lung parenchymal $\mathrm{MHClI}^{\text {high }}$ cells can be divided in $\mathrm{CDCs}$, moDCs, moMrs, and M $\theta$ s}

To assess DC/M $\theta$ canonical genes expression by reverse transcriptase-quantitative PCR (qPCR), all six populations 

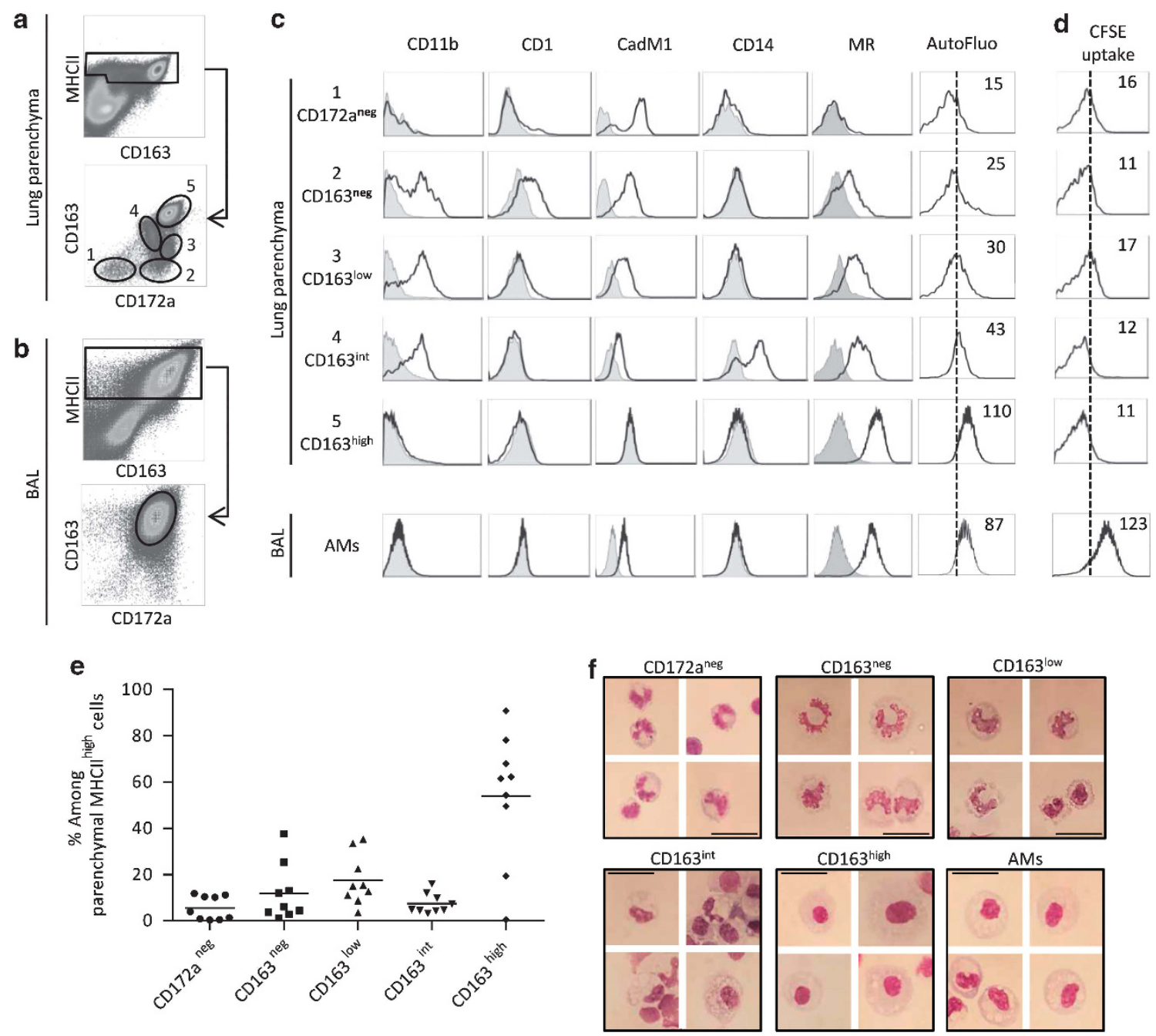

Figure 1 Phenotype of lung dendritic cells (DCs) and macrophages (M $\theta$ s). Bronchoalveolar lavages (BALs) and lung parenchymal cells were stained for multi-color flow cytometry. (a) In the parenchyma, DCs were identified as MHCI ${ }^{\text {high }}$ and divided into five subsets based on the expression of CD163 and CD172a. (b) In BAL, alveolar M $\theta$ (AMs) were MHCII ${ }^{\text {pos }}$. (c) Expression of the phenotypic markers CD11b-like, CD1, CadM1, CD14, and mannose receptor (MR)-like on DC subsets and AMs, along with their autofluorescence, were assessed by flow cytometry. The filled histogram represents the appropriate control isotype. (d) Cells present in the lumen of the intermediate lobe were carboxyfluorescein succinimidyl ester (CFSE) stained before being collected in the BAL. Next, parenchymal cells were extracted and CFSE expression was assessed by flow cytometry. Results are representative of

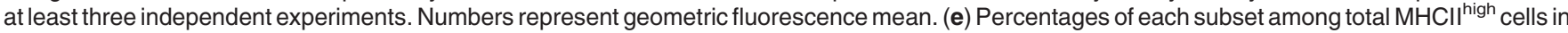
the parenchyma. Each point represents one animal. (f) Cells were sorted, spun onto slides, and stained by a May-Grünwald-Giemsa coloration, to observe their morphology. Scale bar, $50 \mu \mathrm{m}$. All data are representative of at least three independent experiments.

were sorted. As shown in Figure 2a, both CD172 $\mathrm{a}^{\text {neg }}$ and $\mathrm{CD} 163^{\text {neg }}$ populations expressed high levels of FLT3, suggesting that they belong to the $\mathrm{CDC}$ lineage. $\mathrm{CD} 172 \mathrm{a}^{\text {neg }}$ cells were the only ones expressing XCR1. These data, along with their $\mathrm{CadM1}^{\text {pos }} / \mathrm{CD} 11 \mathrm{~b}-$ like $\mathrm{e}^{\text {neg }} / \mathrm{MR}$-like ${ }^{\text {neg }}$ phenotype, indicate their adscription to the $\mathrm{CDC} 1$ subset. $\mathrm{CD} 163^{\text {neg }}$ cDCs were $\mathrm{FLT} 3^{\text {high }} / \mathrm{CD} 172 \mathrm{a}^{\text {pos }} / \mathrm{XCR} 1^{\text {neg }}$, indicating that they correspond to the $\mathrm{CDC} 2$ subset. As observed in human and mouse $\mathrm{cDC} 2{ }^{28,29} \mathrm{CD} 163^{\text {neg }} \mathrm{cDCs}$ also expressed the myeloid genes CSF1R, CCR2, and CX3CR1, whose expressions overlapped with monocyte-derived cells. The CD163 ${ }^{\text {neg }}$ cells, like human $\mathrm{CDC} 2$, expressed higher levels of Langerin ${ }^{30}$ and FceRI $\alpha^{31}$ compared with all other subtypes. As CD $163^{\text {neg }}$ cells presented a bimodal expression of CD11b-like, we sought to test CD11b-like ${ }^{\text {neg }}$ and CD11b-like ${ }^{\text {pos }}$ cells separately for CDC2 markers: both cell populations expressed FceRI $\alpha$ (data not shown), comforting the belonging of the overall $\mathrm{CD} 163^{\text {neg }} \mathrm{DC}$ population to the $\mathrm{CDC} 2$ subset.

$\mathrm{CD} 163^{\text {low }}$ cells expressed the myeloid genes MerTK and CD64 at an intermediate level between cDCs and AMs, whereas they expressed less CCR2 and CX3CR1 than CDC2 but more than AMs. They also expressed the M $\theta$ marker CSF1R but to a lesser extent than the $\mathrm{CD} 163^{\text {int }}$ cells. Along with their DC morphology, these data suggest that they correspond to moDCs. Interestingly, and in parallel with their CadM1 expression, CD172 $\mathrm{a}^{\text {neg }}$ but also $\mathrm{CD} 163^{\text {neg }}$ and $\mathrm{CD} 163^{\text {low }}$ cells expressed CD103, a cDC1 marker in mouse lung. The CD163 ${ }^{\text {int }}$ population showed the same gene expression profile as 

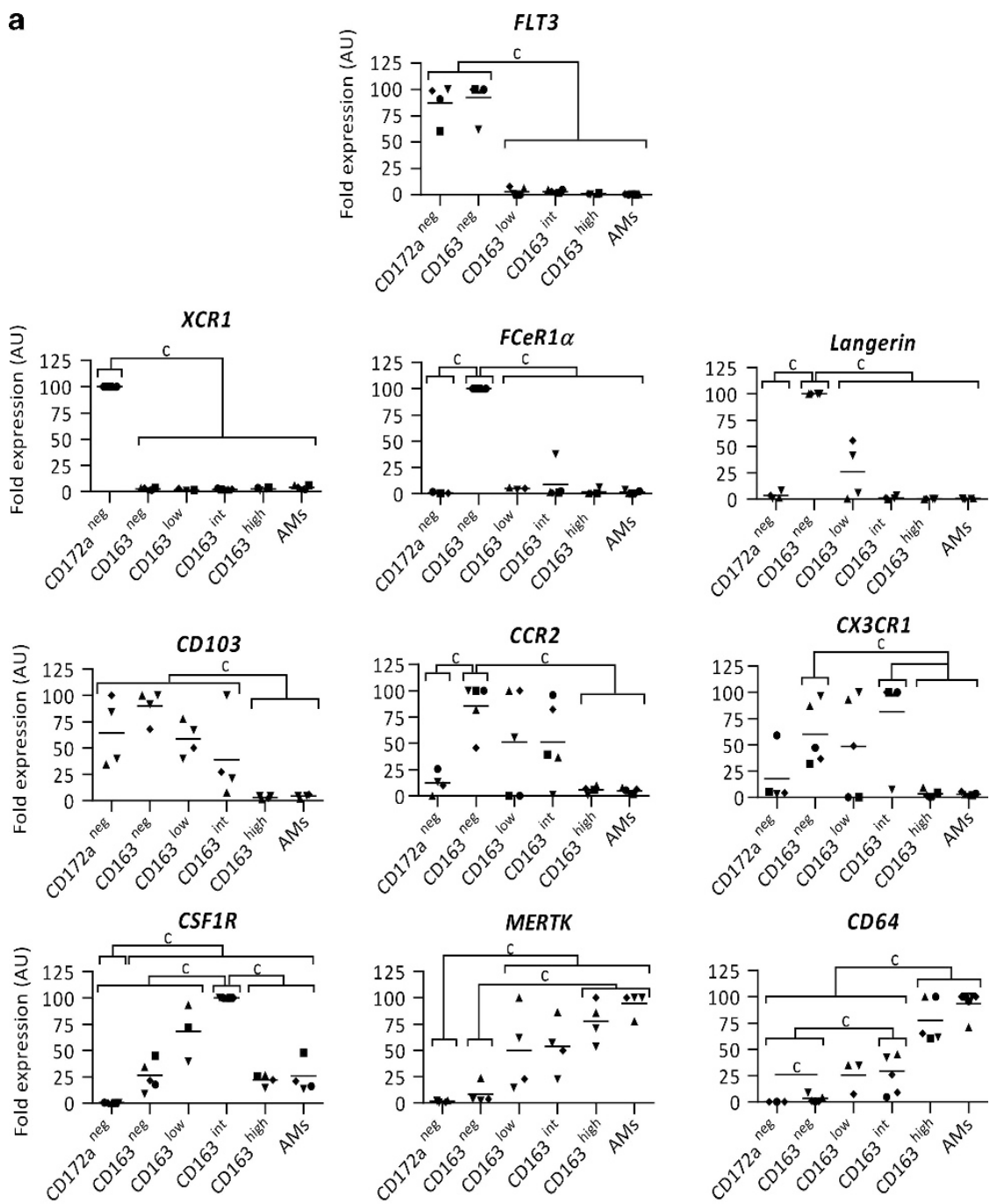

CD64
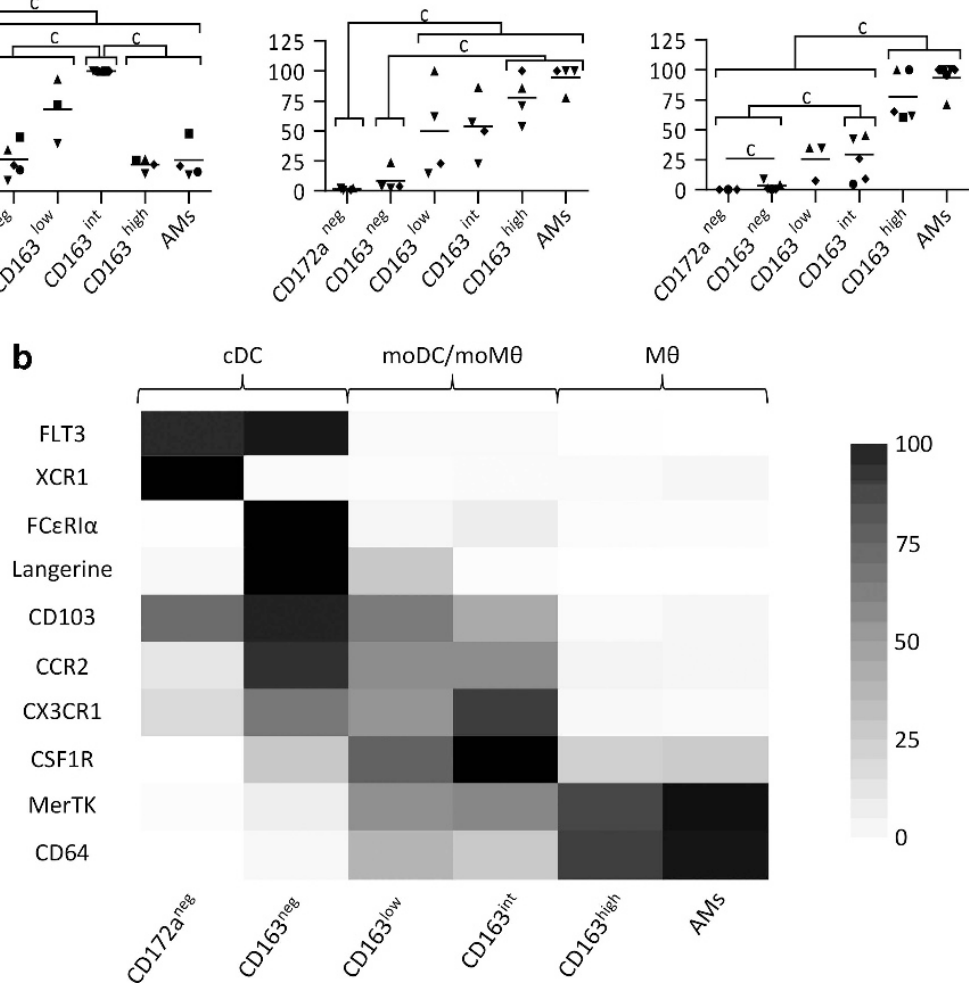

Figure 2 Lung parenchymal $\mathrm{MHCI}{ }^{\text {high }}$ cells can be segregated in conventional dendritic cells (cDCs), monocyte-derived cells, and macrophages (M $\theta \mathrm{s}$ ). The five DC subsets and alveolar MOs (AMs) were gated as in Figure 1 and sorted by flow cytometry. (a) mRNA expression levels of FLT3, XCR1, Fc\&R1 $\alpha$, Langerin, CD103, CCR2, CX3CR1, CSF1R, merTK, and CD64 in DC subsets and AMs were assessed by quantitative real-time PCR. For each gene, data were normalized to the reference gene RPS24 (ribosomal protein S24) expression and presented as relative expression (arbitrary units (AUs)): for each animal, the population with the highest expression for this gene was considered as 100 and the other populations were normalized to it. Each symbol represents one animal. (b) Heat map synthesizing the means (color scale on the right) of real-time PCR data from (a). Statistic signs c: $P<0.05$, b: $P<0.01$, a: $P<0.001$ with a Mann-Whitney test. moDC, monocyte-derived DC; moM $\theta$, monocyte-derived macrophages; 9 , macrophages. 
CD163 ${ }^{\text {low }}$ DCs but it did show M $\theta$ morphology as well, which suggest that they could belong to a monocyte-derived $\mathrm{M} \theta$ $(\mathrm{moM} \theta)$ population. Finally, AMs and parenchymal CD163 $3^{\text {high }}$ cells presented a very similar expression pattern, with no expression of CCR2 and CX3CR1, and a higher expression of MerTK and CD64 compared with all the other cells.

This whole transcriptomic profile was similar in tracheal mucosa cells (Supplementary Data $\mathbf{1 b}$ ).

\section{$\mathrm{CD}_{172 a^{\text {neg }}}, \mathrm{CD}_{163^{\text {neg }}}$, and CD163 ${ }^{\text {low }}$ cells present DC functionalities, whereas CD163 ${ }^{\text {int }}$, CD163 $^{\text {high }}$, and AMs behave like Mos}

Two of the main properties of mature DCs are their capacities to migrate toward the lymph node against a CCL21 gradient and to activate naive T cells. Thus, we tested the capacity of in vitromatured lung populations to migrate toward CCL21 in a transwell assay. Strikingly, the three populations presenting DC morphology, i.e., the CD172a ${ }^{\text {neg }}, \mathrm{CD} 163^{\text {neg }}$, and $\mathrm{CD} 163^{\text {low }}$ cells migrated toward CCL21 (Figure 3a). To compare the migration of the various populations in spite of their different proportions in the upper chamber, we calculated their migration index ${ }^{32}$ as the percentage of cells having migrated for each population (Figure $3 \mathbf{b}$ ). The results highlighted that both $\mathrm{cDCs}$ had a higher migration capacity compared with $\mathrm{CD} 163^{\text {low }}$ cells, and that $\mathrm{CD} 163^{\text {int }}, \mathrm{CD} 163^{\text {high }}$, and AM subsets did not substantially migrate toward CCL21.

We next examined whether these subsets possessed the capacity to induce naive allogeneic $\mathrm{T}$-cell proliferation (Figure 3c-e and Supplementary Data 2). As lungs were obtained from conventional, outbred animals, we experienced high variability in the percentages of responding $\mathrm{T}$ cells according to the degree of allogeneicity of each DC/T-lymphocyte match. For instance, $\mathrm{CD} 4{ }^{+} \mathrm{T}$-cell spontaneous proliferation ranged from 0.2 to $8.0 \%$, and upon CD $163^{\text {neg }}$ cells stimulation from 4.6 to $52.5 \%$. Similarly, $\mathrm{CD}^{+}$T-cell spontaneous proliferation ranged from 1.0 to $15.6 \%$, and upon $\mathrm{CD} 163^{\text {neg }}$ cells stimulation from 7.3 to $55.5 \%$. CD3 ${ }^{+} \mathrm{CD}^{-}{ }^{-} \mathrm{CD}{ }^{-} \gamma \delta \mathrm{T}^{-}$cells $^{33}$ presented a higher spontaneous proliferation ranging from 0.8 to $42.8 \%$, and upon CD163 ${ }^{\text {neg }}$ stimulation reached 4.1 to $66.7 \%$ of proliferation. We thus compared the proliferation index of each experiment as described in Methods. As shown in Figure 3c, CD163 ${ }^{\text {neg }}$ cDCs were the best at inducing proliferation of $\mathrm{CD} 4{ }^{+} \mathrm{T}$ cells, followed by $\mathrm{CD} 172 \mathrm{a}^{\text {neg }}$ cells. The two $\mathrm{cDC}$ subsets were equally potent at inducing $\mathrm{CD}^{+}$T-cell proliferation (Figure 3d). $\mathrm{CD} 163^{\text {low }}$ moDCs induced variable proliferation of $\mathrm{CD} 8{ }^{+}, \mathrm{CD} 4{ }^{+}$, and $\gamma \delta$ $\mathrm{T}$ cells, although without reaching significance. In agreement with their assignment to the M $\theta$ types, the $\mathrm{CD} 163^{\text {int }}, \mathrm{CD} 163^{\text {high }}$, and AM populations did not stimulate T-cell proliferation.

Subsequently, the capacity of each DC/M $\theta$ population to skew differentiation of naive allogeneic $\mathrm{CD} 4{ }^{+} \mathrm{T}$ cells in different Th subsets was tested in vitro. CD172a $\mathrm{a}^{\text {neg }} \mathrm{cDCs}$ induced differentiation of interferon- $\gamma$-producing Th cells (Figure 3f). $\mathrm{CD}_{163^{\text {neg }}} \mathrm{cDCs}$ induced interleukin (IL)-13-producing Th cells (Figure 3g), whereas the three DC populations induced variable degrees of IL-17-producing Th cells (Figure 3h). Next, the capacity of each subset to produce inflammatory cytokines after a lipopolysaccharide/polyinosinic:polycytidylic acid stimulation was studied. The CD163 ${ }^{\text {low }}$ subset produced both IL-1 $\beta$ (Figure 3i) and IL-8 (Figure 3j). Combining their phenotype, morphology, transcriptome, and functional capacities, we can assess that CD172 $\mathrm{a}^{\text {neg }} / \mathrm{XCR} 1^{\text {pos }}$ cells and $\mathrm{CD} 163^{\text {neg }} / \mathrm{CD} 172 \mathrm{a}^{\text {pos }}$ cells correspond to $\mathrm{cDC} 1$ and $\mathrm{cDC} 2$, whereas $\mathrm{CD} 163^{\text {low }}$ cells may correspond to the inflammatory moDC type, as they present monocyte lineage features and DC capacities. The $\mathrm{CD} 163^{\text {int }}$ population also presented monocytederived cell characteristics, but showed $\mathrm{M} \theta$ features, leading us to name them moM $\theta$ s. Finally, CD163 $3^{\text {high }}$ cells could be considered as 'interstitial' AMs.

\section{$\mathrm{DC} / \mathrm{M} \theta$ localization in the respiratory tract}

Both $\mathrm{CDC}$ subsets were more represented in the bronchus and trachea than in the lung parenchyma (Figure 4). The $\mathrm{CD} 163^{\mathrm{low}} / \mathrm{moDC}$ population was equally represented all along the respiratory tract. Finally, the CD163 int $/$ moM $\theta$ s and the CD163 ${ }^{\text {high }}$ 'interstitial' AMs were overrepresented in the lower part of the lung.

\section{$\mathrm{DC} / \mathrm{M} \theta$ sublocalization in respiratory tissues}

Tissue sublocalization was assessed by confocal microscopy (Figure 5). CD172a neg/cDC1 cells were interstitial, mainly localized around the alveoli in the lung parenchyma. CD $163^{\text {neg }}$ cDC2 cells had an intra-epithelial localization in tracheal and bronchial mucosa, and a sub-epithelial localization in the lung parenchyma bronchioles. The $\mathrm{CD} 163^{\mathrm{low}} / \mathrm{moDCs}$ and $\mathrm{CD} 163^{\text {int }} / \mathrm{moM} \theta$ populations cannot be distinguished from one another on these images. Parenchymal CD163 ${ }^{\text {high }}$ cells could be distinguished from AMs in the lung interstitium and in the alveoli lumen, respectively.

\section{IAV infection induces moDCs recruitment}

Having characterized the equivalents of murine $\mathrm{cDC} 1, \mathrm{cDC}$, moDCs, moM $\theta$ s, and AMs in the porcine respiratory tract, we then assessed their recruitment upon IAV infection. Two fieldisolated strains, swine (sw) $\mathrm{H} 1 \mathrm{~N} 2$ and $\mathrm{swH} 3 \mathrm{~N} 2,{ }^{34}$ were tested in order to be able to draw robust, nonstrain-specific conclusions. Three groups of six conventional pigs were inoculated with phosphate-buffered saline (PBS), swH3N2, or swH1N2 (Figures 6a-c), and lungs were collected at 2 days post infection. Cells were extracted from the lobe presenting the higher macroscopic lesion score (cardiac lobe, arrow in Figure 6a) without performing BAL; thus, AMs and CD163 $3^{\text {high }}$ cells could not be distinguished in this experiment. All populations were counted and analyzed by flow cytometry to measure their percentage among total cells (Figures $\mathbf{6 d - f}$ ). The absolute number of each sub-population per cardiac lobe was then calculated. Interestingly, the CD $163^{\text {low }} / \mathrm{moDCs}$ population was the only one that significantly increased after both swH3N2 and swH1N2 infections (Figure 6g). Sorted lung DCs were tested for transcriptomic expressions of IL-12A, IL-4, IL-13, and IL-6, cytokines involved in the induction of respectively Th1, Th2, Th2, and Th17 cells. ${ }^{35}$ CD172a ${ }^{\text {neg }} / \mathrm{cDC} 1$ produced more IL-12A mRNA, the Th1 inducer cytokine, than $\mathrm{CD} 163^{\text {neg }} / \mathrm{cDC} 1$ and $\mathrm{CD} 163^{\text {low }} / \mathrm{moDCs}$, both in mock 

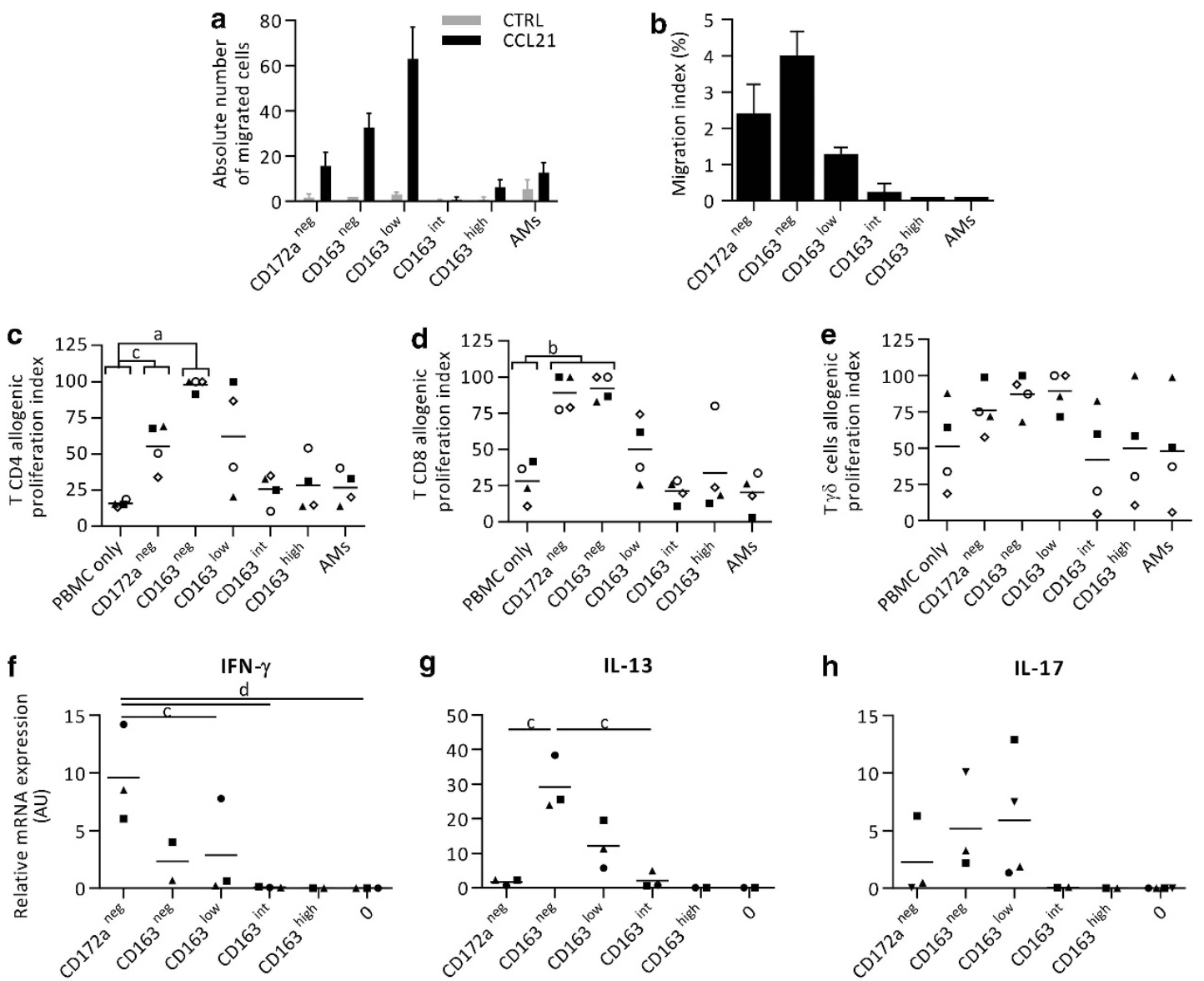

g

IL-13

h

IL-17
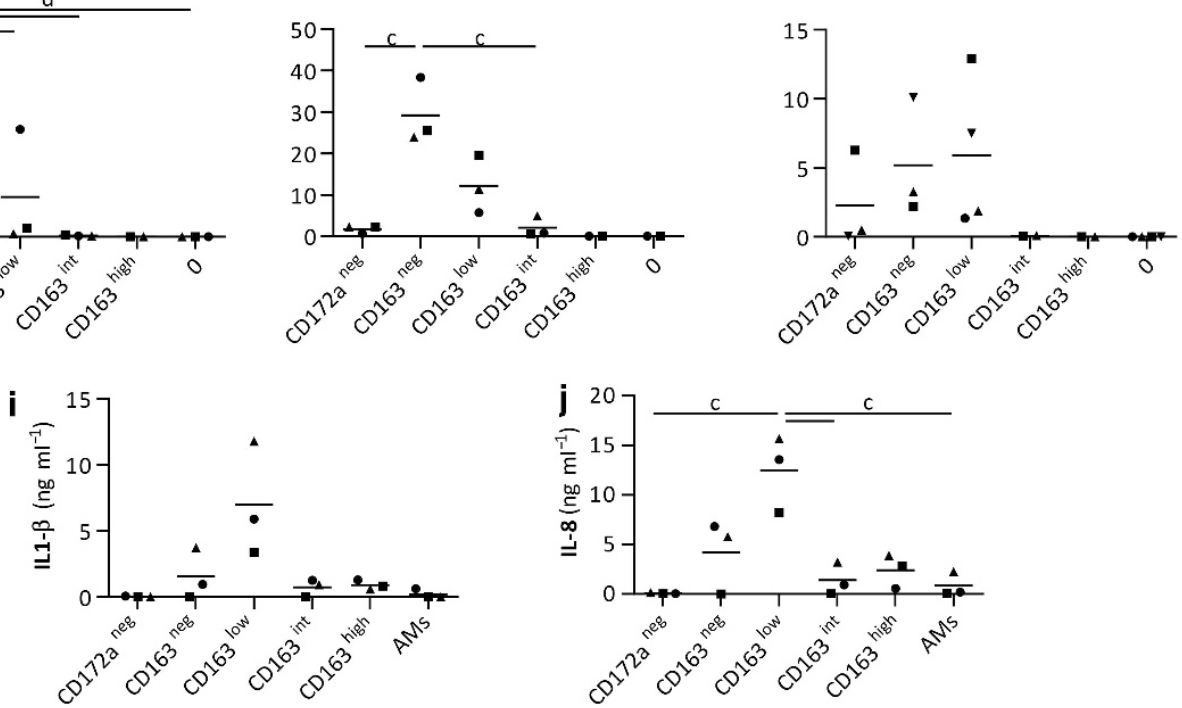

Figure $3 \mathrm{CD} 172 \mathrm{a}^{\text {neg }}, \mathrm{CD} 163^{\text {neg }}$, and CD163 ${ }^{\text {low }}$ cells present functionalities of respectively conventional dendritic cells $(\mathrm{CDC}) 1, \mathrm{CDC} 2$, and inflammatory (inf)DC. Bronchoalveolar lavage (BAL) cells and parenchymal cells were isolated and peripheral blood mononuclear cells (PBMCs) collected as described in the Methods section. DC-enriched parenchymal cells or BAL cells were laid on transwell inserts in contact with $400 \mu$ l of CCL21 previously deposed in the lower chamber. Migrated DCs were collected after $2 \mathrm{~h}$ at $37^{\circ} \mathrm{C}$, stained, and counted by flow cytometry. Results are depicted either as the absolute number of migrated cells (a) or as the following percentage for each population: (number of migrated cells)/(initial number of cells deposed in the upper chamber) $\times 100$ (migration index) (b). Data are the means of triplicates and are representative of three different experiments. (c,d,e) DCs were sorted and plated out at a 1:8 ratio with $10^{5}$ carboxyfluorescein succinimidyl ester (CFSE)-labeled allogeneic PBMCs from specific pathogen-free (SPF) pigs for 5 days at $37^{\circ} \mathrm{C}$. Proliferation of $\mathrm{CD} 3^{+} \mathrm{CD} 4^{+}\left(\mathrm{CD} 4^{+} \mathrm{T}\right.$ cells), $\mathrm{CD} 3^{+} \mathrm{CD} 4^{-} \mathrm{CD} 8 \alpha^{+}\left(\mathrm{CD} 8^{+} \mathrm{T}\right.$ cells), and $\mathrm{CD} 3^{+} \mathrm{CD} 4^{-} \mathrm{CD} 8 \alpha^{-}(\gamma \delta \mathrm{T}$ cells) was assessed by CFSE dilution (see Supplementary Data 2 for gating strategy). For each animal, the highest proliferation value was considered as 100 and the other populations were normalized to it. $(\mathbf{f}, \mathbf{g}, \mathbf{h})$ Lung DCs and macrophages $(\mathrm{M} \theta)$ were sorted and plated out at a 1:10 ratio with previously enriched $2.5 \times 10^{5}$ allogeneic naive CD4 ${ }^{+}$T cells for 3 days. Total RNA was extracted and expressions of mRNA encoding interferon (IFN)- $\gamma$, interleukin (IL)-13, and IL-17 were assessed by quantitative reverse transcriptase-PCR (qRT-PCR). Data were normalized to the expression of the reference gene RPS24 (ribosomal protein S24) and are representative of three distinct experiments. (i,j) The different DC subsets were sorted and cultured for one night with lipopolysaccharide (LPS) and polyinosinic:polycytidylic acid (poly:IC). Interleukins IL-8 and IL1- $\beta$ concentrations in the supernatants were assessed by cytokine beads analysis (CBA). Each symbol represents one animal. d: $P<0.06$, c: $P<0.05$, b: $P<0.01$, a: $P<0.001$ with a Student's $t$-test.

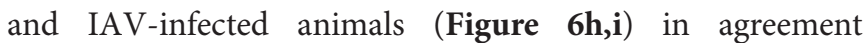
with their Th1-inducing capacities in allogeneic reactions (Figure 3h). Neither IL-13 nor IL-4 transcripts, the Th2inducing cytokines, were detected (data not shown). Finally, no differences in IL-6 transcription (Figure 3i) were observed between the three DC subsets, both at steady state and upon infections, in agreement with the absence of a specific allogenic Th17-inducing DC subset. 


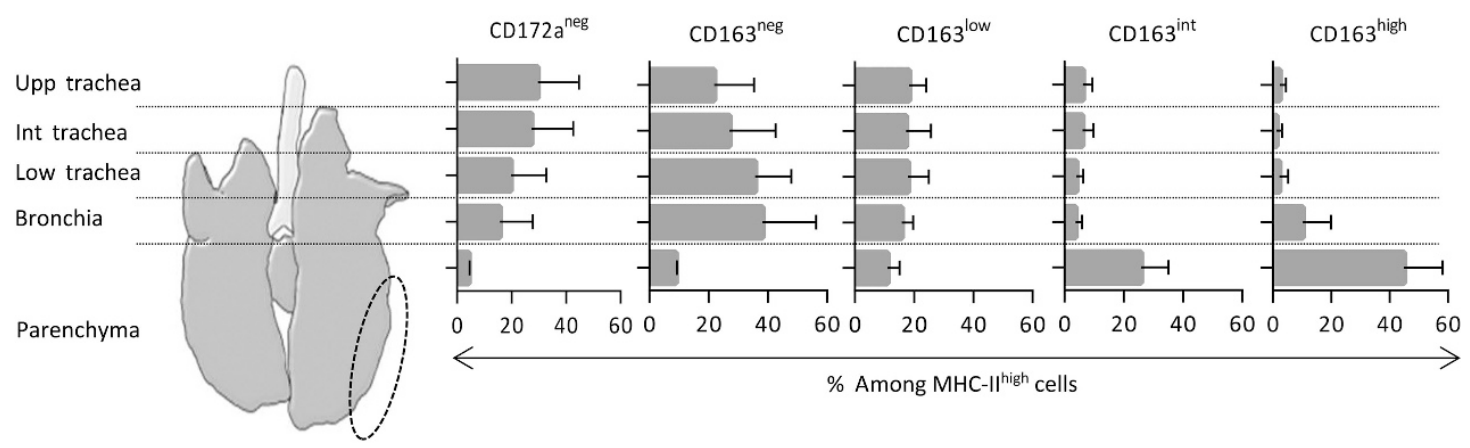

Figure 4 Dendritic cells (DCs) and macrophages (M $\theta$ s) repartition in the respiratory tract. The five DC/M $\theta$ subsets were gated as in Figure 1 and their percentage among all $\mathrm{MHCl}{ }^{\text {high }}$ cells were compared in lung parenchyma, bronchial epithelium, and three different parts of the tracheal mucosa. Int, intermediate; Low, lower; Upp, upper.

\section{$\mathrm{CD}_{163} \mathrm{neg} / \mathrm{cDCs}$ and $\mathrm{CD} 163^{\mathrm{low}} / \mathrm{moDCs}$ can present IAV NP antigen to $\mathrm{CD}^{+}{ }^{+}$effector/memory $\mathrm{T}$ cells}

To further investigate the functions of lung DCs, we tested the capacity of each DC/M $\theta$ lung population to stimulate antigenspecific $\mathrm{CD}^{+}$and $\mathrm{CD}^{+}$effector/memory cells, using enriched spleen $\mathrm{T}$ cells from $\mathrm{H} 1 \mathrm{~N} 1$-vaccinated pigs and autologous cell-sorted lung DC/M $\theta$ loaded with purified IAV nucleoprotein (NP). Given the difficulty of such an experiment, it was only performed on three pigs, which obviously led to an important variability in the results. Both $\mathrm{CD} 163^{\text {neg }} / \mathrm{cDC} 2$ and $\mathrm{CD} 163^{\mathrm{low}} / \mathrm{moDCs}$ appeared capable of presenting NP antigens to effector/memory $\mathrm{CD} 4{ }^{+} \mathrm{T}$ cells (Figure 7a and Supplementary Data 2). Surprisingly, despite their strong capacity to activate naive allogeneic $\mathrm{CD} 4^{+}$and $\mathrm{CD}^{+} \mathrm{T}$ cells, to produce IL-12A and to induce Th1 cells, $\mathrm{CD} 172 \mathrm{a}^{\text {neg }} / \mathrm{cDC} 1$ appeared unable to present antigen to $\mathrm{CD} 4{ }^{+}$ or $\mathrm{CD}^{+}$effector/memory $\mathrm{T}$ cells (Figure $7 \mathbf{a}, \mathbf{b}$ ) under the experimental conditions tested here.

\section{DISCUSSION}

In order to develop valid and substantial alternative models to study respiratory pathologies, current knowledge on murine and human immune networks must be extended to other species. Here we show the potential of pig as a pertinent and intermediate model between mouse and human by ascribing six porcine respiratory $\mathrm{DC} / \mathrm{M} \theta$ cell types to their mouse and human counterparts, based on the recent unified nomenclature. ${ }^{12}$

Porcine AMs were CD163 $3^{\text {high }} / \mathrm{CD} 11 \mathrm{~b}$-like ${ }^{\text {neg }}$ and expressed high levels of MerTK and CD64, as in mouse $e^{28,36}$ and in human. ${ }^{37}$ Conversely to the other lung DCs/M $\theta$ s, pig AMs expressed virtually no CCR2 or CX3CR1, in agreement with an origin that would be independent from blood monocytes, as recently demonstrated for mouse AMs. ${ }^{13,14}$ Interestingly, we observed an AM-like population, the CD163 $3^{\text {high }}$ 'interstitial' AMs, unambiguously localized in the interstitium and representing $>50 \%$ of the $\mathrm{MHC}$ - $\mathrm{II}^{\text {high }}$ parenchymal cells. It is noteworthy that this population has been observed in mouse lung, ${ }^{27}$ without raising much interest. However, according to their frequency in pig parenchyma and to the essential role of AMs in the downmodulation of virus-induced inflammation in mouse $^{19}$ and in pig, ${ }^{38}$ the presence of 'interstitial' AMs in human lungs and the respective roles of alveolar and 'interstitial' AMs deserve further investigations.

A third $\mathrm{M} \theta$-like cell was described as $\mathrm{MHC}-\mathrm{II}^{\text {high }}$ lung population: the $\mathrm{CD} 163^{\text {int }}$ cells. According to their $\mathrm{M} \theta$ features and their CCR2 and CX3CR1 expressions, they can be considered as moM $\theta$ s. Interestingly, interstitial $\mathrm{M} \theta \mathrm{s}$, which are phenotypically distinct from AMs, have been described in mice. They express similar major histocompatibility complex II (MHC-II) levels as DCs and strongly downmodulate the allergic immune response. ${ }^{39}$ The CD163 $3^{\text {int }} / \mathrm{moM} \theta$ s described here might be their pig counterpart (Figure 8). Again, to our knowledge, this population has never been reported in human.

The CD $163^{\text {low }}$ cells presented full DC functionalities. Their frequency increases in the lung on IAV infection and they secrete the pro-inflammatory cytokines IL-1 $\beta$ and IL-8/CXCL8 when stimulated. They also appeared potent in antigen-specific restimulation of the $\mathrm{CD} 4$ recall response. Thus, they were ascribed to the inflammatory moDC population. In mouse, lung inflammatory $\mathrm{DCs}^{15}$ have been defined as FceRI $\alpha^{\text {pos }}$ $\mathrm{CD} 4^{\text {pos }}$. In pig, they expressed intermediate levels of CD64 compared with AMs and did not express FceRI $\alpha$ conversely to $\mathrm{CD} 163^{\text {neg }} / \mathrm{cDC} 2$, which strongly expressed FceRI $\alpha$. In human, inflammatory DCs (from arthritic synovial fluid and ascites), cDC1, and cDC2 (from blood and lung) express FcERI $\alpha{ }^{31,40,41}$ These data suggest that FceRI $\alpha$ might not be the best transspecies marker of inflammatory moDCs.

Characterization of these inflammatory moDCs is very relevant, considering not only their pathological role in mice during an IAV infection ${ }^{26,42}$ but also their involvement in asthma. ${ }^{15}$ For example, during the last decade, CCR2 pharmacological antagonists have been developed, patented, and tested in different human inflammatory pathologies. ${ }^{43}$ The definition of inflammatory moDCs in pig might allow to better describe, understand, and refine the different modes of action of these and other future drugs to be used for treatment in human.

Finally, two populations presented the hallmarks of cDCs; they expressed FLT3 along with strong migration and antigen presentation capacities. The CD172 $\mathrm{a}^{\text {neg }} \mathrm{CDC}$ expressed XCR1, activated $\mathrm{CD} 8{ }^{+}$better than $\mathrm{CD} 4{ }^{+}$naive allogeneic T cells, and 

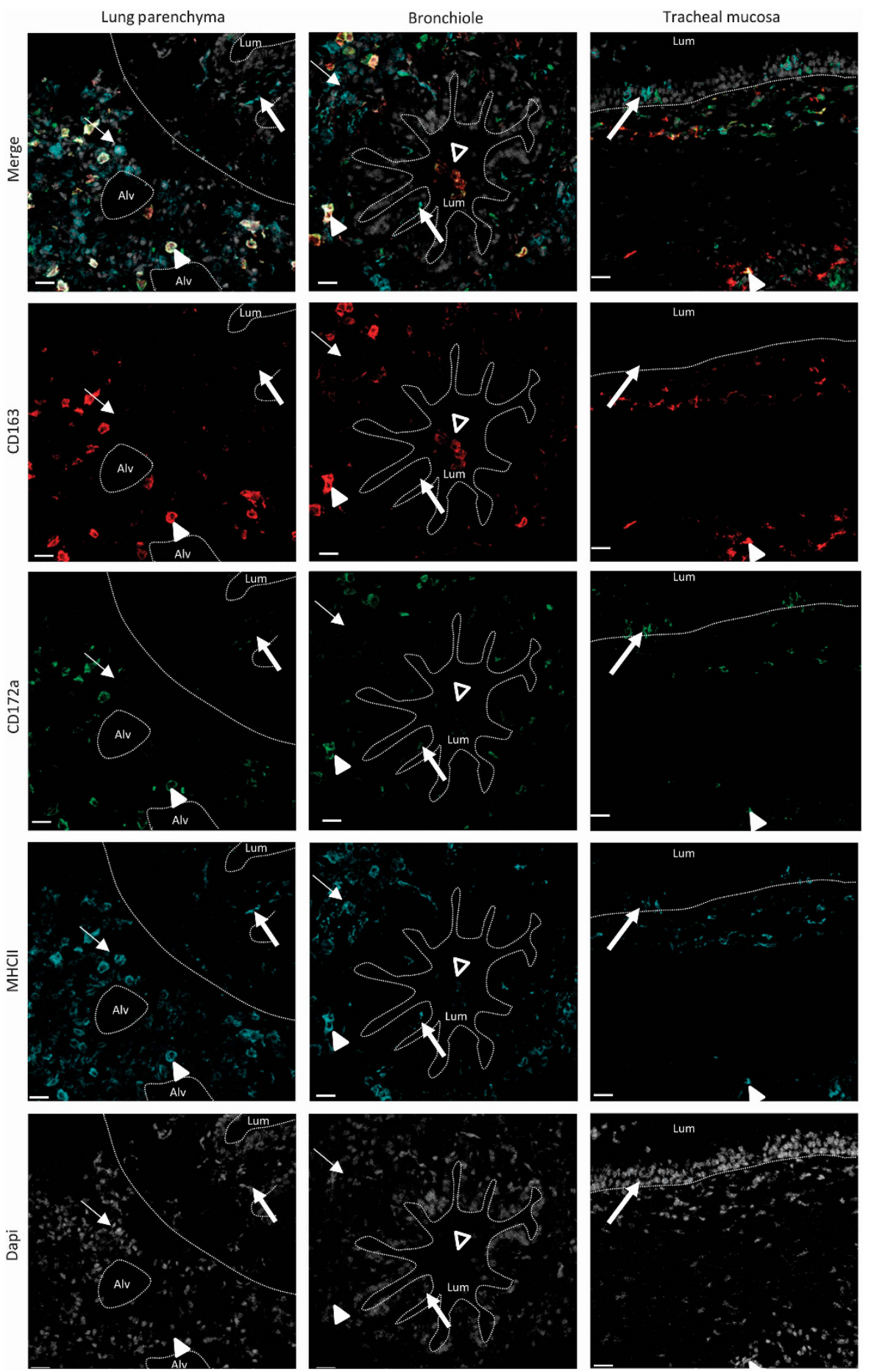

Figure 5 Dendritic cells (DCs) and macrophages (M $\theta$ s) sublocalization. Four DC/M $\theta$ subsets were localized by confocal microscopy on parenchymal and tracheal mucosa cryosections fixed with acetone/methanol and stained for the indicated specificity. Images are representative of at least three pictures from different regions of biopsies from at least two different animals, independently stained. Objective used, $\times 40$ oil immersion. Scale bars, $20 \mu \mathrm{m}$. Thin arrow: CD172a ${ }^{\text {neg; }}$ large arrow: $C D 163^{\text {neg; }}$; filled arrowhead: CD163 ${ }^{\text {high }}$; empty arrowhead: AM.

induced a Th1 response. All in all, these properties clearly defined them as $\mathrm{CDC} 1$. However, they were unable to induce antigen-specific proliferation of effector/memory $\mathrm{CD} 8^{+} \mathrm{T}$ cells. In humanized mice, ${ }^{18}$ both $\mathrm{cDC}$ subsets from the lungs or lymph nodes were able to reactivate memory $\mathrm{CD} 8{ }^{+} \mathrm{T}$ cells.
However, it has been shown in mouse ${ }^{44}$ that although $\mathrm{cDC} 1$ from the lymph node and lung were able to activate naive $\mathrm{CD}^{+}{ }^{+} \mathrm{T}$ cells, only $\mathrm{cDC} 1$ from the lymph node could efficiently activate memory $\mathrm{CD} 8^{+} \mathrm{T}$ cells. The authors hypothesized that the inability of lung $\mathrm{CDC} 1$ to activate memory $\mathrm{CD} 8{ }^{+} \mathrm{T}$ cells 

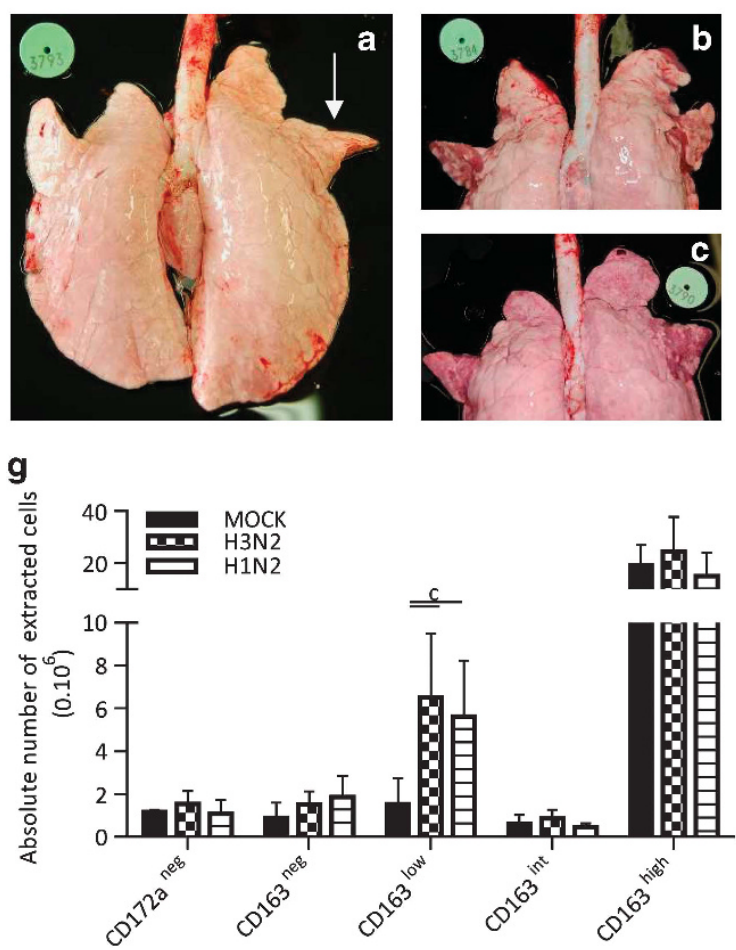
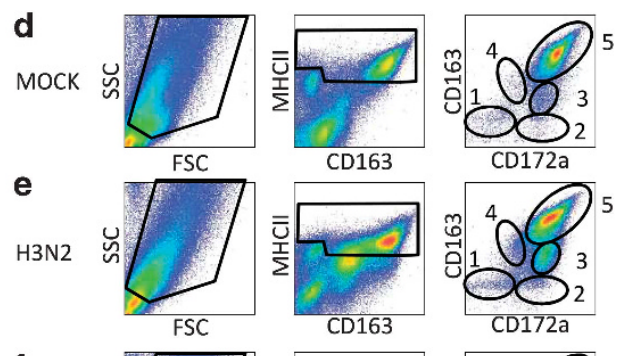

H1N2
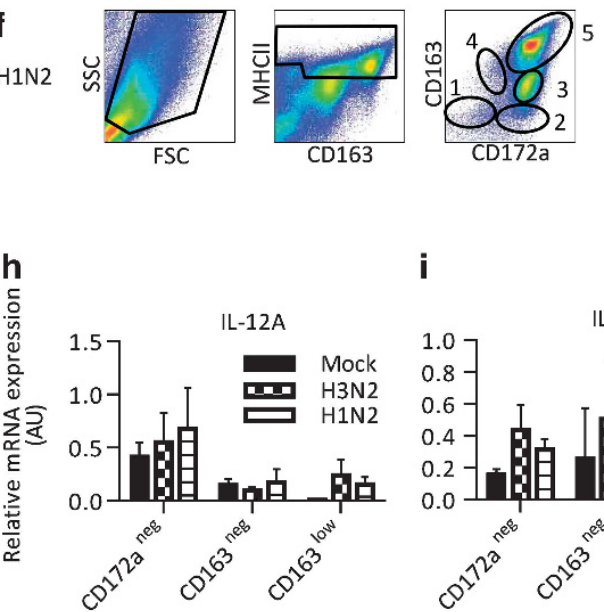

i

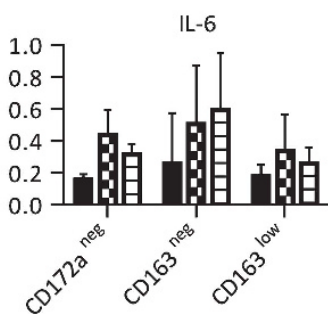

Figure 6 Influenza A virus (IAV) infection induces a recruitment of monocyte-derived dendritic cells (moDCs). Three groups of six pigs were inoculated intratracheally with swH3N2, swH1N2, or PBS and euthanized at 2 days post infection (dpi). Lungs from MOCK- (a), H3N2- (b), and H1N2-infected pigs (c) were sampled. Cells from the cardiac lobe (pointed by the white arrow) were extracted, stained, and analyzed by flow cytometry (d,e,f). Percentages of each population among total extracted cells were represented as means of six pigs for each group (g). c: $P<0.05$ with a Student's $t$-test. Lung-extracted DCs were stained and sorted by flow cytometry. Total RNA was extracted and expressions of mRNA encoding interleukins (IL)-12A (h) and IL-6 (i) were assessed by quantitative real-time PCR. Data were normalized to the expression of the reference gene RPS24 (ribosomal protein S24).

would allow a better priming of naive $\mathrm{T}$ cells, even in conditions in which robust memory predominates, allowing the emergence of $\mathrm{CD} 8{ }^{+} \mathrm{T}$ cells presenting new antigen specificities. Although further in-vivo experiments are required, porcine lung $\mathrm{CDC} 1$ might be closer to murine lung $\mathrm{CDC} 1$ in their low capacity, to reactivate effector/memory $\mathrm{CD} 8{ }^{+} \mathrm{T}$ cells than their human counterparts.

The second $c D C$ subset, $C D 163^{\text {neg }} / \mathrm{CD} 172 \mathrm{a}^{\text {pos }} / \mathrm{XCR} 1^{\text {neg }}$, activated $\mathrm{CD}^{+}{ }^{+}$and $\mathrm{CD}^{+}$naive allogeneic $\mathrm{T}$ cells and induced a Th2 response. Although the association of CD8 ${ }^{+}$ T-cell activation with a Th2 response seems contradictory, it is important to point out that our results were obtained in the context of an allogeneic reaction, which does not involve crosspriming of $\mathrm{CD} 8{ }^{+} \mathrm{T}$ cells, and induces a strong helper response. $\mathrm{CD} 163^{\text {neg }} \mathrm{CDC}$ induced an antigen-specific proliferation of $\mathrm{CD}^{+}{ }^{+}$effector/memory $\mathrm{T}$ cells and, in a less clear-cut way, of $\mathrm{CD}^{+} \mathrm{T}$ cells, as previously observed in mouse cDC2. ${ }^{45}$ According to these properties and in agreement with mouse data, ${ }^{15} \mathrm{CD} 163^{\text {neg }}$ cells can be ascribed to the cDC2 lineage.

Pig lung cDC2 expressed strong levels of Langerin. We have previously described its expression in some skin $\mathrm{CDC} 2 .^{20,21}$ In addition, it has been recently shown in human that Langerin is expressed by some cDC2 from the dermis, lung, tonsil, and liver, and it is rapidly induced in blood $\mathrm{CDC} 2$ on tumor growth factor- $\beta$ exposure. ${ }^{30}$ Interestingly, similar to human $\mathrm{cDC} 2$ (ref. 18) porcine $\mathrm{cDC} 2$ are localized in close proximity with epithelial cells, a potential source of tumor growth factor- $\beta$, whereas in mouse $\mathrm{CDC} 1$ have been described at this location. ${ }^{46}$ In line with this, CD103 and CadM1, integrins involved in homophilic or heterophilic interactions with epithelial cells, ${ }^{47,48}$ are expressed by pig $\mathrm{CDC} 1$ and $\mathrm{cDC} 2 . \mathrm{CD} 103$ is a marker of $\mathrm{CDC1}$ in mouse peripheral tissues, ${ }^{46,49}$ whereas CadM1 is a marker of $\mathrm{CDC1}$ in different tissues of mice, humans, pigs, sheep, ${ }^{21,32,50}$ and bats (Ginhoux and Dutertre, personal communication). In swine lung, these two markers are expressed on the two cDC subsets and on moDCs. In our previous work on porcine skin, we observed that CadM1 was expressed on dermal $\mathrm{CDC} 1$ and on intra-epithelial Langerhans cells. ${ }^{20}$ We can thus hypothesize that in pig, and potentially in other species, CadM1 and CD103 may be expressed on CDC1 regardless of their location, but also on any DC in an epithelial environment.

It is important to highlight that the most striking similitudes between swine and human are related to the $\mathrm{CDC} 2$ population: conversely to the mouse one, swine and human CDC2 are localized in or next to the tracheal and bronchial epithelia and express FcERI $\alpha$ (Figure 8). These two properties, associated with the Th2-inducing capacity of $\mathrm{cDC} 2$, might imply similar allergen responses of these two species as opposed to mouse. Indeed, intraepithelial localization of $\mathrm{cDC} 2$ must facilitate their sampling of noninvasive antigens such as allergens, whereas FcERI $\alpha$ expression might allow self-amplification ${ }^{51}$ or 

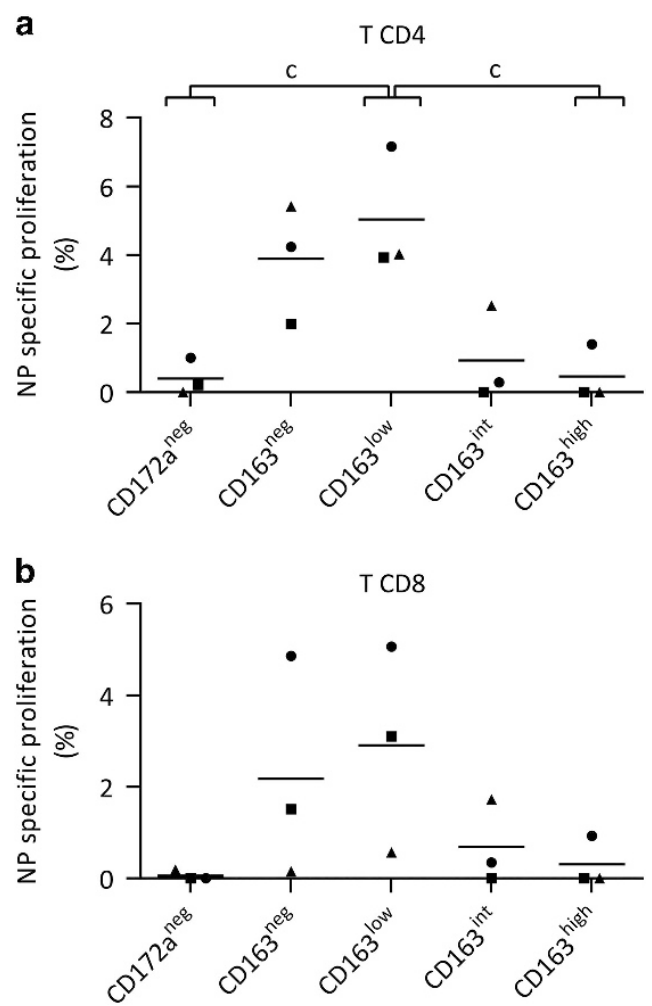

Figure $7 \mathrm{CD} 163^{\text {neg }}$ conventional dendritic cells (cDCs) and CD163 low monocyte-derived DCs (moDCs) induce antigen-specific proliferation of $\mathrm{CD}^{+}$memory $\mathrm{T}$ cells. Three pigs were intramuscularly vaccinated twice with inactivated $\mathrm{H} 1 \mathrm{~N} 1$ virus supplemented with a CD8-inducing adjuvant (ISA201-SEPPIC), and lung and spleen cells were collected at day 60. Lung DCs and macrophages (MOs) were sorted and either incubated alone or charged with recombinant influenza nucleoprotein (NP), then plated with carboxyfluorescein succinimidyl ester (CFSE)-stained, enriched T cells, depleted of myeloid cells, B cells, and $\gamma \delta$ T cells, at a 1:20 ratio. $\mathrm{CD}^{+}{ }^{+}\left(\mathrm{CD} 3^{+} \mathrm{CD}^{+}\right)(\mathrm{a})$ or $\mathrm{CD} 8^{+}\left(\mathrm{CD} 3^{+} \mathrm{CD} 4^{-} \mathrm{CD} 8 \alpha^{+}\right)$(b) proliferation was assessed by flow cytometry after 5 days. For each subset of each pig, the percentage of proliferation induced by unloaded DCs/M $\theta$ s was substracted from the percentage of proliferation induced by NP-loaded $\mathrm{DCs} / \mathrm{M} \theta$ s, in order to represent NP-specific proliferation only. c: $P<0.05$ with a Student's $t$-test.

autoregulation $^{52}$ of the pathological inflammation, differently from the murine $\mathrm{CDC} 2$. Thus, pig respiratory system might be considered a better model than mouse for human allergic syndromes.

On the contrary, during pathologies targeting epithelial cells such as IAV infection, the deep localization of $\mathrm{CDC1}$ in porcine and in human ${ }^{18}$ pulmonary tissues might undermine their access to antigens and thus lessen their role in the induction of the immune response compared with that in mouse. Different $\mathrm{CDC} 1$ and $\mathrm{CDC} 2$ localizations between mice and humans might explain why human $\mathrm{CDC} 2$ are shown to be more involved in the induction of anti-IAV CD8 response $^{18}$ than their mouse counterparts. ${ }^{53}$ It would be of great interest to test this hypothesis by monitoring the role of $\mathrm{CDC} 1$ and $\mathrm{CDC} 2$ in the initiation of anti-IAV CD8 immune response in pig.

Indeed, as stated before, the porcine respiratory and immune systems are similar to the human one at many levels. In addition, unlike mice, pigs are IAV natural hosts that are able to be infected with the same strains as human. We showed here that it was possible to use pig as a pertinent model for respiratory immune parameters and to study each population of $\mathrm{DC} / \mathrm{M} \theta$ as precisely as in mouse. It is noteworthy to emphasize the importance of working on different complementary species such as mouse, nonhuman primate and nonconventional models such as pig, ferret, or horse, in order to draw more robust conclusions, which allow an easier translation to human clinic.

\section{METHODS}

Animals, in vivo infections, and tissue collection. For phenotypic and functional assays, tissue samples were obtained from 5- to 7-month-old Large White conventionally bred sows from UEPAO, Tours, France.

IAV infection experiments were conducted at CReSA (Barcelona, Spain), in compliance with the Ethical Committee for Animal Experimentation of the institution (Universitat Autonoma de Barcelona). The treatment, housing, and husbandry conditions conformed to the European Union Guidelines (Directive 2010/63/ $\mathrm{EU}$ on the protection of animals used for scientific purposes). Animal care and procedures were in accordance with the guidelines of the Good Laboratory Practices under the supervision of the Ethical and Animal Welfare Committee of the Universitat Autònoma de Barcelona (number 1189) and under the supervision of the Ethical and Animal Welfare Committee of the Government of Catalonia (number 5796). Eighteen pigs (7-8 weeks old, LandraceXPietrain) were housed in separate isolation rooms and were randomly assigned to three experimental groups of six pigs. The animals were seronegative to IAV (ID Screen Influenza A Antibody Competition ELISA, ID-Vet, Grabels, France) at the time of the experiment. On day 0, one group of pigs was intratracheally inoculated with $3 \times 10^{6.3} \operatorname{TCID}_{50}$ of a swH3N2 virus (A/Swine/Spain/SF32071/2007) in $2 \mathrm{ml}$ inoculum produced on Madin-Darby canine kidney (MDCK) cells. Another group was similarly inoculated with $3 \times 10^{7.2} \mathrm{TCID}_{50}$ per $2 \mathrm{ml}$ of a swH1N2 virus (A/Swine/Spain/SF12091/2007). The third group was mock infected, receiving $2 \mathrm{ml}$ of PBS. Each of the three groups was euthanized at 2 days post infection and cardiac lobs were collected.

For the antigen-specific presentation assay, experiments were conducted at PFIE (Tours, France), in accordance with the animal welfare experimentation recommendations under the responsibility of I Schwartz (authorization 00783.02). The animal experiment protocol was approved by the French national ethics committee CEEA Val de Loire. At days 1 and 30, three 2- to 4-month-old Large White pigs were injected intramuscularly with $2 \mathrm{ml}$ of $\mathrm{H} 1 \mathrm{~N} 1$ vaccine composed of PBS, $18.5 \mu \mathrm{g} \mathrm{ml}^{-1}$ inactivated A/Swine/Paris/2590/2009 and ISA201VG adjuvant (SEPPIC, Paris, France). Pigs were euthanized at day 60. The lung and spleen were collected.

Lung and spleen cell isolation. A BAL procedure was performed twice on the isolated left lung with $250 \mathrm{ml}$ of PBS $+2 \mathrm{~mm}$ EDTA (PBS/ EDTA), to collect AMs. Next, a 1-cm slice of external lung parenchyma was dissected from the same lung. For in vivo-infected tissues, the whole cardiac lobe was dissected without performing any BAL, resulting in the extraction of 60-170 million live cells with no significant differences between conditions. Tracheal mucosa was separated from the cartilage with pliers. Tissues were minced and incubated in nonculture-treated Petri dishes, to avoid differential plastic adherence of $\mathrm{M} \theta \mathrm{s}$ and $\mathrm{DCs}$, for $2 \mathrm{~h}$ at $37^{\circ} \mathrm{C}$ in complete RPMI, consisting of RPMI 1640 supplemented with $100 \mathrm{IU} \mathrm{ml}^{-1}$ penicillin, $100 \mathrm{mg} \mathrm{ml}^{-1}$ streptomycin, $2 \mathrm{~mm} \mathrm{L-glutamine}$, and $10 \%$ inactivated fetal calf serum (FCS) (all from Invitrogen, Paisley, UK), containing $2 \mathrm{mg} \mathrm{ml}^{-1}$ collagenase D (Roche, Meylan, France), $1 \mathrm{mg} \mathrm{ml}^{-1}$ dispase (Invitrogen), and $0.1 \mathrm{mg} \mathrm{ml}^{-1}$ Dnase I (Roche). Cells were passed through $40 \mu \mathrm{m}$ cell strainers and red blood cells lysed with erythrocytes 

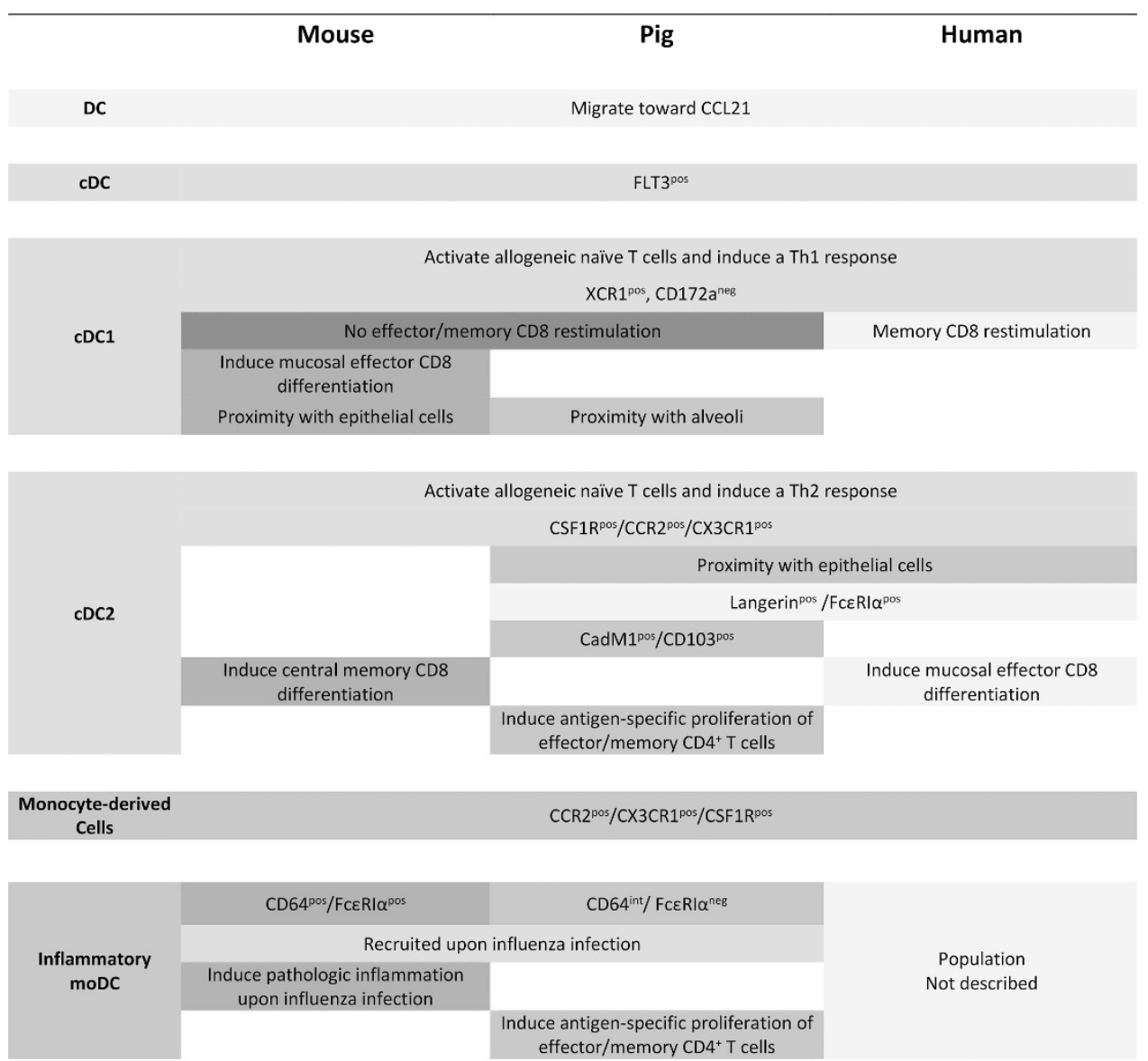

\begin{tabular}{|c|c|c|}
\hline moMacro & MHCII high $/$ MerTK $^{\text {pos }} /$ CD64 & $\begin{array}{c}\text { Pos } \\
\text { Not described }\end{array}$ \\
Interstitial AMs & Autofluorescent/CD11b-like ${ }^{\text {neg }}$ & $\begin{array}{c}\text { Population } \\
\text { Not described }\end{array}$ \\
CD163
\end{tabular}

AMs

Autofluorescent/CD11b-like $e^{\text {neg }} /$ CD163 ${ }^{\text {high }} /$ CD64 $4^{\text {pos }} /$ MerTK $^{\text {high }} / C C R 2^{\text {neg }} / C X 3 C R 1^{\text {neg }}$

(Bibliographic references can be found in the main text)

Figure 8 Comparison of mouse, pig and human lung DCs/M $\theta$ s. DCs, dendritic cells; M $\theta$ s, macrophages.

lysis buffer (10 mm $\mathrm{NaHCO}_{3}, 155 \mathrm{~mm} \mathrm{NH}_{4} \mathrm{Cl}$, and $10 \mathrm{mM}$ EDTA). Next, cells were washed with PBS-EDTA, counted, and step-frozen in FCS $+10 \%$ dimethyl sulfoxide (Sigma-Aldrich, St Louis, MO).

Spleen cells were extracted by scraping with a scalpel blade and collected in PBS $1.3 \mathrm{~mm}$ citrate, then filtered on a $100-\mu \mathrm{m}$ strainer in complete RPMI, and enriched on Ficoll-Hypaque density gradient (Amersham Biosciences, Uppsala, Sweden). Red blood cells were lysed as described above.

Ex-vivo CFSE staining assay. In order to stain the alveolar cells ex vivo, the intermediate lobe was sampled and injected with $20 \mathrm{ml}$ of $50 \mu \mathrm{M}$ CFSE (Invitrogen) via the connecting bronchiole, while being rubbed for a better diffusion in the alveoli. Next, it was clamped and after 30 min incubation at $37^{\circ} \mathrm{C}$, alveolar cells were collected by one lavage with $10 \mathrm{ml} \mathrm{FCS}$ and two lavages with $15 \mathrm{ml}$ PBS-EDTA. Two additional lavages were performed to eliminate remaining alveolar cells. The lobe was then minced and enzymatically digested as described above, to retrieve interstitial lung cells.
Flow cytometry analysis. Cell surface stainings were performed in PBS-EDTA supplemented with 5\% horse serum and 5\% swine serum for $30 \mathrm{~min}$ on ice. Primary antibodies and their working dilutions are listed in Table 1. The anti-CD11b antibody used (M1/70) recognizes murine and human $\mathrm{CD} 11 \mathrm{~b}$ but had never been described in pig. It must bind to one out of the three potential orthologs of CD11 $\mathrm{c}$ and CD11b in pig, namely CD11R1, CD11R2, or CD11R3. ${ }^{54}$ Thus, for clarity we referred to the antigen recognized by this antibody as 'CD11b-like'. The anti-MR also being an anti-human antibody, it will be referred to as 'MR-like'.

Matched isotype controls for mouse IgG1, IgG2b, and IgG2a were purchased from Invitrogen and were used at the same concentration as the corresponding antibody. Secondary antibodies, anti-mouse IgG1, IgG2b, IgG2a coupled to Alexa-488, Phycoerythrin-PE, Tricolor, or Alexa-647 were from Invitrogen and were used at a 1/200 dilution. Between labelings, cells were washed twice with PBS-EDTA. Cells from IAV-infected pigs were then fixed in $4 \%$ paraformaldehyde (EMS, Hatfield, PA) before flow cytometry analysis. Samples were acquired on 
Table 1 Antibodies used for flow cytometry, microscopy, and CBA assays (working dilutions are specified for flow cytometry assays. A 1/40 dilution was used for each antibody for depletions)

\begin{tabular}{|c|c|c|c|c|c|}
\hline Antibody & Clone & Isotype & Species & Working dilution & Supplier \\
\hline Anti-CD172a & $74-22-15,74-22-15 a$ & $\lg G 1, \lg G 2 b$ & Mouse & $1 / 500$ & Antibody \\
\hline Anti-CD4 & PT90A, 74-12-4 & $\lg G 2 a, \lg G 2 b$ & Mouse & $1 / 400$ & Washington \\
\hline Anti-CD3 & 8E6 & $\lg G 1$ & Mouse & $1 / 100$ & State \\
\hline Anti-CD8a & $76-2-11$ & $\operatorname{lgG} 2 a$ & Mouse & $1 / 50$ & (Pullmann, \\
\hline Anti-CD8b & PG164A & $\lg G 2 a$ & Mouse & & WA) \\
\hline Anti-lgM & PG145A & $\lg M$ & Mouse & & \\
\hline Anti-humCD14 & TUK4 & $\lg G 2 a$ & Mouse & $1 / 100$ & \\
\hline Anti-CD25 & K231.3B2 & $\operatorname{lgG1}$ & Mouse & & \\
\hline PE-conjugated & & & & $1 / 20$ & \\
\hline Anti-humMR-like & 122D2.08 & $\lg G 1$ & Mouse & $1 / 100$ & Dendritics (Lyon, France) \\
\hline Anti-humCadM1 & $3 \mathrm{E} 1$ & $\lg Y$ & Chicken & $1 / 250$ & MBL (Woburn, MA) \\
\hline Anti-humCD11b (CD11b-like) & $\mathrm{M} 1 / 70$ & $\lg G 2 b$ & Rat & $1 / 100$ & BD Pharmingen \\
\hline Anti-humCD21 (CD21-like) & B-ly4 & $\lg \mathrm{G} 1$ & Mouse & & (Le Pont de Claix, France) \\
\hline Cytokines & \multicolumn{2}{|l|}{ Recombinant cytokines } & \multicolumn{3}{|c|}{ Biotinylated antibody } \\
\hline IL1- $\beta$ & \multicolumn{2}{|l|}{ R\&D Systems 681-PI } & \multicolumn{3}{|c|}{ R\&D Systems BAF6811 } \\
\hline CXCL8 /IL-8 & \multicolumn{2}{|l|}{ R\&D Systems 535-IN } & \multicolumn{3}{|c|}{ R\&D Systems BAF535 } \\
\hline
\end{tabular}

Abbreviations: CBA, cytometric beads assay; IL1- $\beta$, interleukin-1 $\beta$; MR, mannose receptor.

a FACS-Calibur (BD-Biosciences, Oxford, UK) or sorted on a MoFlo ASTRIOS (Beckman-Coulter, Paris, France). For sorting, dead cells were excluded by Dapi staining (Sigma-Aldrich). Acquired data were analyzed using FlowJo software (version X.0.6; Tree Star, Ashland, OR).

Microscopy. Lung parenchyma biopsies and tracheal mucosa pieces were snap-frozen in OCT (Sakura, Paris, France) and conserved at $-80^{\circ} \mathrm{C}$. Cryosections $(7 \mu \mathrm{m})$ were obtained using a cryostat (Leica CM3050S, Nanterre, France). Sections were fixed in methanol/acetone $(1: 1)$ at $-20{ }^{\circ} \mathrm{C}$ for $20 \mathrm{~min}$ and stained using previously described anti-swine antibodies, matched isotype controls, and isotype-specific secondary antibodies. Sections were mounted in SlowFade mounting medium (Invitrogen). Slides were examined on a LSM510 confocal microscope (Zeiss, LePecq, France), using a $40 \times$, oil-immersion objective (MIMA2 Platform, INRA, Jouy en Josas, France), and analyzed with Zen 2012 Software (Zeiss, Jena, Germany).

May-Grünwald-Giemsa staining and histology. Sorted cells were deposed on microscope slides (Superfrost, Thermo, Villebon sur Yvette, France) by cytocentrifugation and stained with May-GrünwaldGiemsa stain. Images were acquired with a Leica Leitz DMRB microscope equipped with a $\times 63$ oil-immersion objective (numerical aperture 1.3) and a DP50 imaging camera coupled to the CellF software (Olympus, Tokyo, Japan).

DC enrichment and stimulation. Cells were cultured in complete RPMI. Preparations were enriched in DC by gradient ${ }^{20}$ (Optiprep;
Nycomed Pharma, Oslo, Norway). Enriched preparations routinely contained $5-25 \%$ of DC/M $\theta$ as checked by flow cytometry. For transwell and cytokine production assays, enriched DCs were matured by a $24-\mathrm{h}$ in vitro culture in complete RPMI supplemented with $10 \mu \mathrm{g} \mathrm{ml}^{-1}$ lipopolysaccharide and polyinosinic:polycytidylic acid (Sigma-Aldrich).

Transwell assay. A Chinese Hamster Ovary (CHO) clone expressing porcine CCL21-GFP has been derived as previously described. ${ }^{21}$ Four hundred microliters of supernatants from this clone or from the parental CHO cells were deposed in the lower wells of a 24-well plate. DCs or AMs were enriched and stimulated as described above and resuspended in complete RPMI at $1 \times 10^{6}$ cells per ml. Next, $100 \mu$ l were deposed on the inserts (Costar, $5 \mu \mathrm{m}$ pore filter, Corning, NY). After $2 \mathrm{~h}$ at $37^{\circ} \mathrm{C}$, cells having migrated in the lower compartment were stained and counted by flow cytometry.

Mixed lymphocytes reaction assay. Mixed lymphocytes reaction assays were performed as previously described. ${ }^{21}$ Briefly, peripheral blood mononuclear cells from large, white, specific pathogen-free pigs (Anses, Ploufragan, France) were CFSE stained and re-suspended in $\mathrm{X}$-vivo medium (Ozyme, Saint-Quentin-en-Yvelines, France) supplemented with $2 \%$ FCS and penicillin/streptomycin at $3 \times 10^{6}$ cells per $\mathrm{ml}$ (or $1 \times 10^{6}$ cells per $\mathrm{ml}$ for enriched naive CD ${ }^{+} \mathrm{T}$ cells) and $100 \mu \mathrm{l}$ per well were plated in a 96-well U-bottom plate. The sorted DCs were mixed with the allogeneic CFSE-labeled T cells at a 1:8 ratio. Cells were cultured for 5 days in X-vivo medium $+2 \%$ FCS + penicillin/streptomycin before staining with anti-CD3, anti-CD4, and 
Table 2 Primers used for qPCR

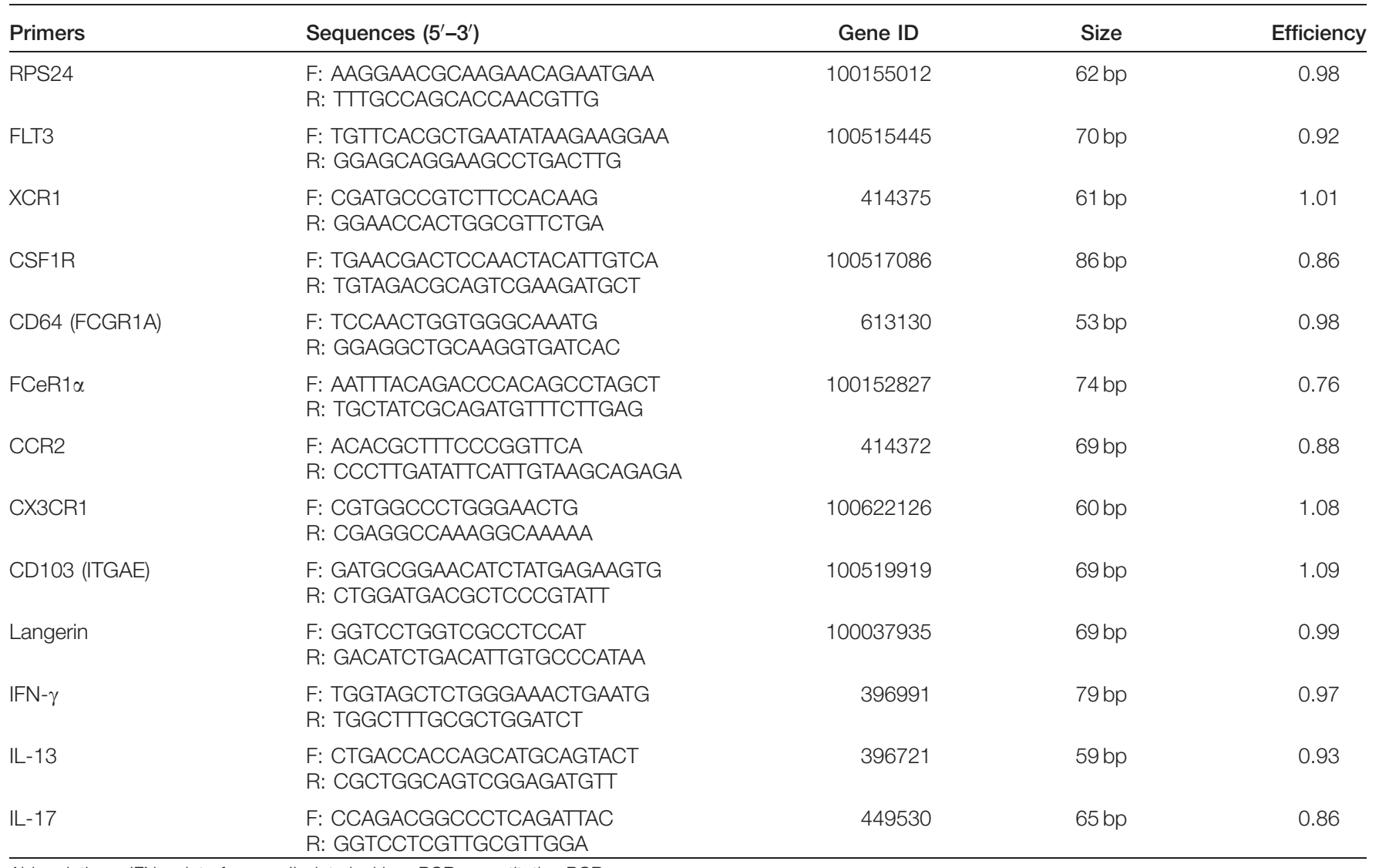

Abbreviations: IFN- $\gamma$, interferon- $\gamma$; IL, interleukin; qPCR, quantitative PCR.

anti-CD $8 \alpha$ antibodies, and flow cytometry analysis. For each of the four distinct experiments, the cell subtype inducing the highest percentage of $\mathrm{T}$-cell proliferation was considered as 100 and the percentage of T-cell proliferation induced by the other cell subtypes of the same experiment were normalized to it.

For naive $\mathrm{CD} 4{ }^{+} \mathrm{T}$-cell functional polarization, allogeneic naive $\mathrm{CD}^{+} \mathrm{T}$ cells were enriched by depletion of myeloid cells, B cells, natural killer cells, $\gamma \delta \mathrm{T}, \mathrm{CD} 8{ }^{+} \mathrm{T}$ cells, and memory $\mathrm{CD} 4^{+} \mathrm{T}$ cells. Fresh peripheral blood mononuclear cells from Melanoma Libechov Minipig pigs $^{55}$ were stained with anti-CD172a, anti-CD21-like, anti-IgM, anti-IgL, anti-CD16, anti-CD8 $\alpha$, anti-MHC-II, and anti- $\gamma \delta \mathrm{T}$ cell receptor, all at a $1 / 40$ dilution. They were then incubated with goat anti-mouse IgG microbeads (Miltenyi-Biotech, Bergisch Gladbach, Germany) at a 1/5 dilution, washed, and passed on an LD column (Miltenyi-Biotech) for depletion. Naive $T$ cells represented $>70 \%$ of the collected cells. They were then mixed with the sorted DCs/M $\theta$ s at a 1:10 ratio. Seventy-two hours later, cells were lysed and RNA extracted. Reverse transcriptase-quantitative PCR were then performed as stated below using interferon- $\gamma$-, IL-13-, and IL-17specific primers.

Cytokine detection. Sorted DCs were re-suspended in complete RPMI at $1 \times 10^{6}$ cells per $\mathrm{ml}$ and plated in $200 \mu \mathrm{l}$ per well of a 96 -well $\mathrm{U}$-bottom plate for one night at $37^{\circ} \mathrm{C}$ with $10 \mu \mathrm{g} \mathrm{ml}^{-1}$ lipopolysaccharide and polyinosinic:polycytidylic acid. The supernatants were frozen at $-20{ }^{\circ} \mathrm{C}$ until cytokine detection. Concentrations of IL- $1 \beta$ and IL- 8 were assessed by cytometric beads assay for simultaneous detection of 10 swine cytokines. Antibodies and recombinant cytokines used are listed in Table 1. Capture antibodies were covalently coupled to the surface of fluorescent Cyto-Plex carboxylated Microspheres (Thermo Fisher Scientific, Courtaboeuf, France) according to the manufacturer's instructions. Each capture antibody was applied to a given microsphere category. All assays were made in duplicates. Fifty microliters of samples or standards, diluted in diluent buffer (PBS $0.5 \times$ and Tris buffer $0.5 \times$ ), supplemented with $2.5 \%$ bovine serum albumin, $0.5 \%$ polyvinylalcohol (Sigma-Aldrich), and $0.8 \%$ polyvinylpyrrolidone (Sigma-Aldrich) were incubated in membrane filter-bottomed microplates (MultiScreen HTS BV $1.2 \mu \mathrm{m}$ Opaque Non-sterile, Millipore, Darmstadt, Germany) with 2,000 beads per well of each antibody-coated beads. Beads were washed with washing buffer (PBS $10 \times($ Thermo Fisher Scientific), Tris $0.5 \mathrm{M}, \mathrm{pH}$ 7.2, 1:1) by aspiration. Twenty-five microliters of biotinylated detection antibodies $\left(1 \mu \mathrm{g} \mathrm{ml}^{-1}\right.$ diluted in assay buffer) were added and incubated for $90 \mathrm{~min}$. Fifty microliters of PE-labelled streptavidine $\left(5 \mu \mathrm{g} \mathrm{ml}^{-1}\right.$ diluted in assay buffer, Molecular Probes) were added in each well after three washes, followed by $30 \mathrm{~min}$ incubation. Beads were then washed and re-suspended in PBS before acquisition on a Guava easyCyte 6HT-2L cytometer (Millipore). The results were analyzed using FloCytomix Pro software (eBioscience, Paris, France). A five-parameter logistic regression model was used to fit the curve.

Antigen-specific presentation assay. For antigen-specific presentation assay, spleen cells were collected from pigs vaccinated as described above. Dead cells were eliminated on an Optiprep gradient. Cells were then enriched in $\mathrm{T}$ lymphocytes by depletion of myeloid 
cells, B cells, and $\gamma \delta$ T cells. They were stained with anti-CD172a, antiCD21-like, anti-IgM, anti-IgL, and anti- $\gamma \delta$ TCR, all at a $1 / 40$ dilution, and then with goat anti-mouse IgG microbeads at a $1 / 5$ dilution. Cells were subsequently washed and passed on an LS column (MiltenyiBiotech) for depletion and they were CFSE stained. The sorted lung $\mathrm{DCs} / \mathrm{M} \theta$ s were re-suspended in X-vivo medium $+2 \% \mathrm{FCS}+$ penicillin/streptomycin, and 20,000 cells were plated in $200 \mu \mathrm{l}$ per well of a 96-well U-bottom plate. For each subset of each pig, one well was then incubated at $37^{\circ} \mathrm{C}$ for $90 \mathrm{~min}$ with medium alone and another well with $2 \mu \mathrm{g} \mathrm{ml}^{-1}$ recombinant IAV NP, produced as previously described. ${ }^{56}$ After centrifugation, the NP-containing medium was discarded and 400,000 CFSE-stained T cells from the same pig were added to each well. Cells were cultured for 5 days at $37^{\circ} \mathrm{C}$ before staining with anti-CD3, anti-CD4, and anti-CD $8 \alpha$ antibodies, and flow cytometry analysis. In order to represent the NP-specific proliferation only, the percentage of proliferation induced by unstimulated DCs/ $\mathrm{M} \theta \mathrm{s}$ was subtracted from the percentage of proliferation induced by NP-loaded DCs/M $\theta$ s.

RNA extraction. Total RNA from sorted DCs/M $\theta$ s or cultured allogeneic naive $\mathrm{T}$ cells were extracted using the Arcturus PicoPure RNA Isolation kit (ThermoFisher Scientific, St Aubin, France) according to the manufacturer's instructions. Contaminating genomic DNA was removed using a Qiagen RNase free DNase set (Courtaboeuf, France).

Real-time qPCR. RNA was reverse transcribed using random hexamers and the Multiscribe reverse transcriptase (ThermoFisher Scientific). All cDNA were examined for the frequency of different transcripts using qPCR. All qPCR reactions were performed in $25 \mu \mathrm{l}$ volumes using iTaq Universal SYBR Green Supermix (Biorad, Hercules, CA). Primers are detailed in Table 2. Relative quantification was determined using the $\Delta \mathrm{Ct}$ method and normalized to expression of the reference gene RPS24 (ribosomal protein S24). This gene has been chosen as the reference gene because of its highly stable expression in the different DC and MФ lung subsets, and upon IAV infection (data not shown), as compared with other genes previously shown as stable in pig lungs: $G A P D H$, RPL19, and HPRT. ${ }^{57}$

Statistical analysis. All data were analyzed using the GraphPad Prism v5.0 statistical software package (GraphPad Software, La Jolla, CA). Statistical tests applied to each data set are indicated in the relevant figure legend.

SUPPLEMENTARY MATERIAL is linked to the version of the paper at http://www.nature.com/mi

\section{ACKNOWLEDGMENTS}

We thank Christophe Staub and the UEPAO staff for their work and help in samples collection. In addition, we thank the PFIE staff for the vaccination experiment and the CReSA Cat3 staff, especially Lorena Cordoba and Raquel Maeso, and the staff in the animal facility at CReSA, for their support in the infections experiments and the cell sorting. We thank Céline Deblanc and SPPAE staff, Anses Ploufragan, for access to specific pathogen-free pigs and help in sample treatment. We thank Sandrine Truchet for her help with the MGG images and the INRA confocal microscope platform MIMA2. Finally, we thank Javier Dominguez for the CCL21-GFP-expressing clones. The research leading to these results has received funding from the European Community's Seventh Framework Program (FP7, 2007-2013, NADIR project), Research Infrastructures Action, under the grant agreement number FP7-228393 (NADIR project), and from the project AGL2010-22200-C02-01 from the Spanish Ministry of Science and Innovation.

\section{DISCLOSURE}

The authors declare no conflict of interest.

c) 2016 Society for Mucosal Immunology

\section{REFERENCES}

1. Rogers, C.S. et al. Disruption of the CFTR gene produces a model of cystic fibrosis in newborn pigs. Science 321, 1837-1841 (2008).

2. Rogers, C.S. et al. The porcine lung as a potential model for cystic fibrosis. Am. J. Physiol. Lung Cell. Mol. Physiol. 295, L240-L263 (2008).

3. Gennai, S. et al. Effects of cyclosporine a in ex vivo reperfused pig lungs. Microcirculation 21, 84-92 (2014).

4. Zhu, H. et al. Infectivity, transmission, and pathology of human-isolated H7N9 influenza virus in ferrets and pigs. Science 341, 183-186 (2013).

5. Meurens, F., Summerfield, A., Nauwynck, H., Saif, L. \& Gerdts, V. The pig: a model for human infectious diseases. Trends Microbiol. 20, 50-57 (2012).

6. Dawson, H.D. et al. Structural and functional annotation of the porcine immunome. BMC Genomics 14, 332 (2013).

7. Pampusch, M.S., Bennaars, A.M., Harsch, S. \& Murtaugh, M.P. Inducible nitric oxide synthase expression in porcine immune cells. Vet. Immunol. Immunopathol. 61, 279-289 (1998).

8. Albina, J.E. On the expression of nitric oxide synthase by human macrophages. Why no NO? J. Leuk. Biol. 58, 643-649 (1995).

9. Summerfield, A. Special issue on porcine immunology: an introduction from the guest editor. Dev. Comp. Immunol. 33, 265-266 (2009).

10. Khatri, M. et al. Swine influenza $\mathrm{H} 1 \mathrm{~N} 1$ virus induces acute inflammatory immune responses in pig lungs: a potential animal model for human H1N1 influenza virus. J. Virol. 84, 11210-11218 (2010).

11. Lopez-Robles, G., Silva-Campa, E., Burgara-Estrella, A. \& Hernandez, J. Characterization of antigen-presenting cells from the porcine respiratory system. Res. Vet. Sci. 100, 80-87 (2015).

12. Guilliams, M. et al. Dendritic cells, monocytes and macrophages: a unified nomenclature based on ontogeny. Nat. Rev. Immunol. 14, 571-578 (2014).

13. Guilliams, M. et al. Alveolar macrophages develop from fetal monocytes that differentiate into long-lived cells in the first week of life via GM-CSF. J. Exp. Med. 210, 1977-1992 (2013).

14. Schulz, C. et al. A lineage of myeloid cells independent of Myb and hematopoietic stem cells. Science 336, 86-90 (2012).

15. Plantinga, M. et al. Conventional and monocyte-derived CD11b(+) dendritic cells initiate and maintain $T$ helper 2 cell-mediated immunity to house dust mite allergen. Immunity 38, 322-335 (2013).

16. Boltjes, A. \& van Wijk, F. Human dendritic cell functional specialization in steady-state and inflammation. Front. Immunol. 5, 131 (2014).

17. Demedts, I.K., Brusselle, G.G., Vermaelen, K.Y. \& Pauwels, R.A. Identification and characterization of human pulmonary dendritic cells. Am. J. Respir. Cell Mol. Biol. 32, 177-184 (2005).

18. Yu, C.I. et al. Human CD1c + dendritic cells drive the differentiation of CD103 + CD8 + mucosal effector T cells via the cytokine TGF-beta. Immunity 38, 818-830 (2013).

19. Hussell, T. \& Bell, T.J. Alveolar macrophages: plasticity in a tissue-specific context. Nat. Rev. Immunol. 14, 81-93 (2014).

20. Marquet, F. et al. Characterization of dendritic cells subpopulations in skin and afferent lymph in the swine model. PLoS One 6, e16320 (2011).

21. Marquet, F. et al. Pig skin includes dendritic cell subsets transcriptomically related to human CD1a and CD14 dendritic cells presenting different migrating behaviors and T cell activation capacities. J. Immunol. 193, 5883-5893 (2014).

22. Summerfield, A., Meurens, F. \& Ricklin, M.E. The immunology of the porcine skin and its value as a model for human skin. Mol. Immunol. 66, 14-21 (2015).

23. Lee, J.H. et al. Evaluation of the zoonotic potential of a novel reassortant H1N2 swine influenza virus with gene constellation derived from multiple viral sources. Infect. Genet. Evol. 34, 378-393 (2015).

24. Garten, R.J. et al. Antigenic and genetic characteristics of swine-origin 2009A(H1N1) influenza viruses circulating in humans. Science 325, 197-201 (2009).

25. Barbe, F., Atanasova, K. \& Van Reeth, K. Cytokines and acute phase proteins associated with acute swine influenza infection in pigs. Vet. J. 187, 48-53 (2011).

26. Aldridge, J.R. Jr. et al. TNF/iNOS-producing dendritic cells are the necessary evil of lethal influenza virus infection. Proc. Natl Acad. Sci. USA 106, 5306-5311 (2009).

27. Schneider, C. et al. Alveolar macrophages are essential for protection from respiratory failure and associated morbidity following influenza virus infection. PLoS Pathog. 10, e1004053 (2014). 
28. Gautier, E.L. et al. Gene-expression profiles and transcriptional regulatory pathways that underlie the identity and diversity of mouse tissue macrophages. Nat. Immunol. 13, 1118-1128 (2012).

29. Robbins, S.H. et al. Novel insights into the relationships between dendritic cell subsets in human and mouse revealed by genome-wide expression profiling. Genome Biol. 9, R17 (2008).

30. Bigley, V. et al. Langerin-expressing dendritic cells in human tissues are related to $\mathrm{CD} 1 \mathrm{C}+$ dendritic cells and distinct from Langerhans cells and CD141 high XCR1 + dendritic cells. J. Leukoc. Biol. 97, 627-634 (2014).

31. Segura, E. et al. Human inflammatory dendritic cells induce Th17 cell differentiation. Immunity 38, 336-348 (2013).

32. Crozat, K. et al. The XC chemokine receptor 1 is a conserved selective marker of mammalian cells homologous to mouse CD8alpha + dendritic cells. J. Exp. Med. 207, 1283-1292 (2010).

33. Gerner, W., Kaser, T. \& Saalmuller, A. Porcine T lymphocytes and NK cells-an update. Dev. Comp. Immunol. 33, 310-320 (2009).

34. Baratelli, M. et al. Genetic characterization of influenza A viruses circulating in pigs and isolated in north-east Spain during the period 2006-2007. Res. Vet. Sci. 96, 380-388 (2014).

35. Zhu, J., Yamane, H. \& Paul, W. E. Differentiation of effector CD4 T cell populations (*). Annu. Rev. Immunol. 28, 445-489 (2010).

36. Misharin, A.V., Morales-Nebreda, L., Mutlu, G.M., Budinger, G.R. \& Perlman, $\mathrm{H}$. Flow cytometric analysis of macrophages and dendritic cell subsets in the mouse lung. Am. J. Respir. Cell Mol. Biol. 49, 503-510 (2013).

37. Barbosa, I.L., Gant, V.A. \& Hamblin, A.S. Alveolar macrophages from patients with bronchogenic carcinoma and sarcoidosis similarly express monocyte antigens. Clin. Exp. Immunol. 86, 173-178 (1991).

38. Kim, H.M. et al. Alveolar macrophages are indispensable for controlling influenza viruses in lungs of pigs. J. Virol. 82, 4265-4274 (2008).

39. Bedoret, D. et al. Lung interstitial macrophages alter dendritic cell functions to prevent airway allergy in mice. J. Clin. Invest. 119, 3723-3738 (2009).

40. Foster, B., Metcalfe, D.D. \& Prussin, C. Human dendritic cell 1 and dendritic cell 2 subsets express FcepsilonRI: correlation with serum IgE and allergic asthma. J. Allergy Clin. Immunol. 112, 1132-1138 (2003).

41. Greer, A.M. et al. Accumulation of $\operatorname{BDCA} 1(+)$ dendritic cells in interstitial fibrotic lung diseases and Th2-high asthma. PLoS One 9, e99084 (2014).

42. Lin, K.L., Suzuki, Y., Nakano, H., Ramsburg, E. \& Gunn, M.D. CCR2 + monocyte-derived dendritic cells and exudate macrophages produce influenza-induced pulmonary immune pathology and mortality. J. Immunol. 180, 2562-2572 (2008).

43. Xia, M. \& Sui, Z. Recent developments in CCR2 antagonists. Exp. Opin. Ther. Pat. 19, 295-303 (2009).
44. Belz, G.T., Bedoui, S., Kupresanin, F., Carbone, F.R. \& Heath, W.R. Minimal activation of memory CD8 $+\mathrm{T}$ cell by tissue-derived dendritic cells favors the stimulation of naive CD8 + Tcells. Nat. Immunol. 8, 1060-1066 (2007).

45. Furuhashi, K. et al. Mouse lung CD103 + and CD11bhigh dendritic cells preferentially induce distinct CD4 + T-cell responses. Am. J. Respir. Cell Mol. Biol. 46, 165-172 (2012).

46. Sung, S.S., Fu, S.M., Rose, C.E. Jr., Gaskin, F., Ju, S.T. \& Beaty, S.R. A major lung CD103 (alphaE)-beta7 integrin-positive epithelial dendritic cell population expressing Langerin and tight junction proteins. J. Immunol. 176, 2161-2172 (2006).

47. Cepek, K.L. et al. Adhesion between epithelial cells and T lymphocytes mediated by E-cadherin and the alpha E beta 7 integrin. Nature 372, 190-193 (1994).

48. Masuda, M. et al. The tumor suppressor protein TSLC1 is involved in cell-cell adhesion. J. Biol. Chem. 277, 31014-31019 (2002).

49. Bedoui, S. et al. Cross-presentation of viral and self antigens by skin-derived CD103 + dendritic cells. Nat. Immunol. 10, 488-495 (2009).

50. Contreras, V. et al. Existence of CD8alpha-like dendritic cells with a conserved functional specialization and a common molecular signature in distant mammalian species. J. Immunol. 185, 3313-3325 (2010).

51. Novak, N. et al. FcepsilonRl engagement of Langerhans cell-like dendritic cells and inflammatory dendritic epidermal cell-like dendritic cells induces chemotactic signals and different T-cell phenotypes in vitro. J. Allergy Clin. Immunol. 113, 949-957 (2004).

52. Platzer, B. et al. Dendritic cell-bound IgE functions to restrain allergic inflammation at mucosal sites. Mucosal Immunol. 8, 516-532 (2015).

53. Kim, T.S. \& Braciale, T.J. Respiratory dendritic cell subsets differ in their capacity to support the induction of virus-specific cytotoxic CD8 + T cell responses. PLoS One 4, e4204 (2009).

54. Ezquerra, A., Revilla, C., Alvarez, B., Perez, C., Alonso, F. \& Dominguez, J. Porcine myelomonocytic markers and cell populations. Dev. Comp. Immunol. 33, 284-298 (2009).

55. Horak, V., Fortyn, K., Hruban, V. \& Klaudy, J. Hereditary melanoblastoma in miniature pigs and its successful therapy by devitalization technique. Cell. Mol. Biol. 45, 1119-1129 (1999).

56. Tarus, B. et al. Oligomerization paths of the nucleoprotein of influenza A virus. Biochimie 94, 776-785 (2012).

57. Delgado-Ortega, M., Melo, S. \& Meurens, F. Expression of SOCS1-7 and CIS mRNA in porcine tissues. Vet. Immunol. Immunopathol. 144, 493-498 (2011). 